April 2012

\title{
On the Original Understanding of the Crime of Genocide
}

Hannibal Travis

Follow this and additional works at: https://digitalcommons.usf.edu/gsp

\section{Recommended Citation}

Travis, Hannibal (2012) "On the Original Understanding of the Crime of Genocide," Genocide Studies and Prevention: An International Journal: Vol. 7: Iss. 1: Article 6.

Available at: https://digitalcommons.usf.edu/gsp/vol7/iss1/6

This Articles is brought to you for free and open access by the Open Access Journals at Digital Commons @ University of South Florida. It has been accepted for inclusion in Genocide Studies and Prevention: An International Journal by an authorized editor of Digital Commons @ University of South Florida. For more information, please contact digitalcommons@usf.edu. 


\title{
On the Original Understanding of the Crime of Genocide
}

\author{
Hannibal Travis \\ Florida International University
}

This article is an extended exercise in genocide originalism. Efforts to equate genocidal intent with total racial destruction have grown more common within the UN system over the past decade, including in the cases of Yugoslavia and Sudan. The article surveys evidence that the drafters of the UN Genocide Convention (UNCG) did not define genocidal intent as the intent to destroy an entire race or religion. This evidence shows that the UNCG does not require a deliberate plan or policy of a state to exterminate the members of an entire racial or religious group, or a total genocide. Rather, the UNCG expressly covers partial genocides, genocides in which heads of state do not participate, and genocides motivated by reasons other than racial or religious hatred. This original understanding is manifest in the text of the UNCG, the drafting process, and the course of performance of the UNCG.

Key words: Armenian Genocide, originalism, Sudan, Yugoslavia

Although many genocide scholars adopt sociological or other social scientific definitions of genocide, other leading genocide scholars have propounded a purportedly legal definition that is unduly narrow. Presumably based on the drafting history of the United Nations Convention on the Prevention and Punishment of the Crime of Genocide (UNCG), this narrow definition actually rests upon incomplete and selective references to legal sources with misleading implications. This is apparent during discussions of the question of whether partial genocides, such as by "ethnic cleansing," constitute the crime of genocide.

In this article, I argue that the greatest setback to genocide scholarship, and one largely self-inflicted by some genocide scholars, is the elevation of the requirement of genocidal intent to a standard that is nearly impossible to satisfy because it requires the total destruction of a race. This view has gained ground within the UN system in recent years, as represented by certain findings of the International Court of Justice (ICJ), the International Commission of Inquiry on Darfur (ICID), and the trial chamber of the UN-backed International Criminal Court (ICC). At the root of this misunderstanding is some scholars' equation of the intent to destroy a group-as required by Article II of the UNCG-with a state's deliberate plan or policy to exterminate the members of an entire racial group, or a total genocide. Contrary to this distortion of the UNCG, its drafters and ratifiers rejected efforts to limit genocide to total destruction, a plan or policy of destruction, or a motive of racial hatred. This explains why the UNCG defines genocidal intent so as to include the "intent to destroy ... in part" and why the UN and its members consistently condemn ethnic cleansing as genocide. ${ }^{1}$

\section{Achievements of Genocide Studies}

Scholars, human rights groups, and journalists have made steady progress over the past seven decades in identifying genocide and other crimes against civilian populations and in persuading prosecutors and UN officials to initiate proceedings. Raphael Lemkin 
pioneered this process, which was taken up most effectively by John Barron and René Lemarchand in the 1970s, ${ }^{2}$ by Leo Kuper and Israel Charny in the 1980s, ${ }^{3}$ and by Richard Hovannisian, Vahakn Dadrian, and Robert Melson with regard to the Armenian genocide in the 1980s and 1990s, ${ }^{4}$ with the latter tradition being expanded upon by Thea Halo, Donald Bloxham, and Adam Jones in the 2000s as they documented a general Ottoman Christian genocide. ${ }^{5}$ Since the 1990s, Frank Chalk, Kurt Jonassohn, Helen Fein, R.J. Rummel, Iris Chang, Samantha Power, Ben Kiernan, and Samuel Totten have described other genocides, especially in Africa and Asia. ${ }^{6}$

Even without a standing international criminal court, scholars and other writers have consistently shined the light of truth upon attempts to shroud genocide within the fog of war. Although the convictions of high-ranking Nazis for the Holocaust at the International Military Tribunal, Nuremberg, were for "extermination of the Jews" rather than "genocide," Raphael Lemkin fought as adviser to the tribunal to have destructive acts against Jews, Poles, "Gypsies," and others indicted as genocide, and the concept was used in the indictment. ${ }^{7}$ The British prosecutor at the Nuremberg trial argued that not only Jews but also Belgians, Dutch, French, Norwegians, and Yugoslavs had been victims of genocide. ${ }^{8}$ This echoed Lemkin, who wrote that Poles, Slovenes, and Russians were victims of genocide by mass killings under German "colonization." gued in 1953 that the Soviet Union and its allies were guilty of genocide by killings and deportations to Siberia. ${ }^{10}$

After Lemkin's death in 1959, legal scholars and politicians continued to uncover evidence of genocide in the Soviet Union, China, Nigeria, Pakistan, Vietnam, Cambodia, Iraq, Sudan, and elsewhere. ${ }^{11}$ Scholars helped persuade the UN to establish international criminal tribunals backed by the Security Council for Rwanda and Yugoslavia and to support the drafting of the Rome Statute of the ICC in 1998, and other scholars helped persuade the ICC to exercise its jurisdiction over genocide. ${ }^{12}$

\section{Was the UNCG Only Intended to Apply to Total Genocides?}

In recent years, scholars and genocide prosecutors have had to contend with an excessively pro-perpetrator interpretation of the UNCG. This interpretation would attempt to remove all doubt that a genocide conviction is appropriate by requiring an extraordinarily high showing of the intent to destroy an entire group and its physical and biological remnants accompanied by racist motives completely unrelated to any political purpose. Taken seriously, this interpretation is virtually impossible to satisfy with evidence. Thus, it may undo much of the progress made since 1945 in defining genocide and banning it.

Typically, a treaty like the UNCG is interpreted to give effect to its text, its drafting history, and the case law applying it. ${ }^{13}$ Unfortunately, in the past decade and a half, a form of scholarship has emerged that very selectively takes account of these sources, especially the working papers or travaux préparatoires, and ends up constructing a strained and anti-victim meaning of key phrases in the treaty.

One way not to interpret a treaty is to make its provisions so difficult to satisfy that no concrete case qualifies, making the treaty useless and frustrating its drafters' purposes. Some scholars confine the definition of genocide to a set of very rare and unique events that may never be repeated as long as politicians have enough sense to not write down that they are exterminating races for no good reason. In that sense, the interpretation is very favorable to the perpetrators of genocide who appear as defendants before international criminal tribunals. ${ }^{14}$ It is, therefore, also anti-victim in effect. For example, 
one scholar argues that a "lone genocidal maniac" should receive psychiatric care rather than criminal punishment, whereas a victim might well disagree. ${ }^{15}$

Some scholars and practitioners in the field of genocide law argue that only total biological and physical genocide, and not partial physical genocide or systematic economic or cultural genocide, are covered by the UNCG. ${ }^{16}$ For example, Professor William Schabas (University of Ireland at Galway) suggests that the Holocaust and the Rwandan Genocide represented true, legal genocides, ${ }^{17}$ while the Armenian Genocide, Bangladesh, Biafra, Cambodia, Bosnia and Herzegovina, Kosovo, and Darfur did not. ${ }^{18}$ $\mathrm{He}$ argues that genocide requires a motive to destroy the entire group for reasons of "racist hatred," and that the presence of mixed racial and political/military motives precludes genocidal intent-that is, the specific intent to destroy the group. ${ }^{19}$ Other scholars also equate motive with intent. ${ }^{20}$

Professor Steven Katz (Boston University, formerly Co-Chair of the Academic Committee of the US Holocaust Memorial Museum), adopts a similarly narrow interpretation of the crime of genocide. As a result, Katz opines that there was no genocidal intent in Rwanda. ${ }^{21} \mathrm{He}$ argues that the Hutu-Tutsi conflict in Rwanda was "not genocidal" but rather a war for "tribal domination." 22 Katz also argues that even if the Ottoman Empire killed 775,000 Armenians, this would not be genocide because 17-27\% of Armenians survived and this did not amount to the "complete physical extirpation of every person of Armenian heritage." 23 These equations of genocide with total extermination for no reason, rather than ethnic conflict resulting in mass violence, is analogous to the argument that the Srebrenica massacres did not indicate genocidal intent because they were not total; that is, the women and children of the region lived and the Bosnian Serbs might have had good tactical reasons to massacre Muslim men and boys. ${ }^{24}$

Both Katz and Professor Emeritus Guenter Lewy of the University of Massachusetts at Amherst have argued that only Jews were victims of genocide and all Jews were victims of a total genocide in the Holocaust or Hebrew Shoah. ${ }^{25}$ Lewy explains that the difference is that the Nazis intended to "annihilate physically every man, woman and child" who was Jewish. ${ }^{26}$ Katz similarly identifies the distinction between Jewish genocide and other tragedies on the basis that there was an "intention to kill all Jews without escape." ${ }^{27}$ Lewy argues that killing 40\% of the world's Armenians was not genocide, without noting the rate of Jews surviving the Nazis. ${ }^{28} \mathrm{He}$ contends that, unlike the Holocaust, the Armenian case lacks evidence of a "state-sponsored plan of annihilation." ${ }^{29}$ Likewise, Katz finds no genocide in Armenia because "several hundred thousand Armenians survived" their deportations. ${ }^{30}$ He does not calculate how many Jewish survivors there may have been after $1945 .{ }^{31}$

These total genocide theories differ in some respects. Unlike Katz and Lewy, for example, Schabas does not ignore the fact that the case of the Armenians was among those considered by the drafters of the UNCG as a typical or exemplary case of genocide. ${ }^{32}$ Moreover, Schabas does not deny that Rwanda was a genocide; in fact, he was among the first to allege that Tutsi may be victims of genocide in Rwanda. ${ }^{33}$ Finally, Schabas acknowledges the existence of case law and other legal materials that have found genocide to have been committed where there were survivors. ${ }^{34}$ He simply attempts, as set forth below, to prove that case law wrong.

The total genocide interpretation of the UNCG is flawed whether the text of the UNCG, the UN drafting history, or the case law is considered. The UNCG defines as genocide certain acts with "the intent to destroy, in whole or in part, a national, 
ethnical, racial or religious group." 35 Not one of the acts is restricted to exterminating the group and killing all of its members. In fact, both Lemkin and the UNCG repeatedly emphasize that the victims may survive ${ }^{36}$; thus, they defined genocide to include destructive acts other than killing, such as harming physical and mental health, degrading economic conditions, and interfering with the birth and rearing of children. ${ }^{37}$

The introduction of the words "in part" into Article II of UNCG was achieved by the Norwegian delegation to the drafting committee. ${ }^{38}$ The Norwegian delegation argued that "it was not necessary to kill all the members of a group in order to commit genocide." 39 The Yugoslav delegation agreed, pointing out that "the main characteristic of genocide lay in the intent to attack a group," in other words not simply the intent to exterminate a group. ${ }^{40}$ The Uruguayan delegation proclaimed that partial genocide was already covered by the "intent to destroy a group," because "genocide was committed when a member of a group was attacked." 41 The US delegation concurred, explaining that genocide is not so much about the extermination of groups as the "denial of the[ir] right to live" and insisting that the UNCG must "afford protection to human groups against the acts of individuals." 42 The British delegation noted that "if it was desired to ensure that cases of partial destruction should also be punished, the amendment proposed by the Norwegian delegation would" do that. ${ }^{43}$ The French delegation voted for the Norwegian proposal because it clarified that genocidal intent would include an intent to kill or inflict mental harm on "an individual as a member of a human group." 44

\section{Was the UNCG Intended to Apply Only to Racial Genocides?}

Some scholars contend that specific intent means the intent to destroy the group completely, as part of a plan or policy of total destruction, and not to destroy some of it physically and eliminate the remainder of the group by refugee flight. ${ }^{45}$ They suggest that the use of the phrase dolus specialis in the drafting committee's report requires a motive of racial hatred on the part of génocidaires. ${ }^{46}$ Special intent or dolus specialis is contrasted with dolus eventualis or the conscious disregard of a known risk (recklessness as to the result). ${ }^{47}$ The idea is that a series of massacres alone may not be "calculated to destroy the group, in the sense of genuine [Nazi-style] extermination camps." 48 Scholars use terms such as "racial hatred" and "physical extermination" to describe the intent to destroy thus construed. ${ }^{49}$ One even says that to charge a suspect with genocide, prosecutors need to find a "centralized blueprint for racial annihilation."

The report of the committee on the drafting of the UNCG reveals that genocidal intent was distinguished from the Nazis' premeditated racist extermination campaign against the Jews, so that genocidal intent may exist in more varied circumstances. Among other evidence, a Soviet amendment specifically emphasizing racism and Hitlerism was rejected, and another Soviet amendment underlining the importance of "racial hatred" also failed. ${ }^{51}$ Moreover, language defining genocide as requiring an intent to act "on grounds of national or racial origin" was replaced with a definition including the "intent to destroy [a group] in whole or in part," and language suggesting that perpetrators must be motivated to act "particularly on grounds of" race, nation, or religion was refused. $^{52}$

The point is, delegates declined to link genocide explicitly to racism or Hitlerism because other forms of intent may suffice for the crime of genocide. ${ }^{53}$ The Soviet Union unsuccessfully pressed the view that genocide requires extermination of entire groups "because of their race and nationality." M4 Most importantly, the other delegates turned 
back a proposed Soviet amendment which would have required acts "particularly on grounds of national or racial origin or religious belief" because most delegates believed that "the destruction of a human group on any grounds should be forbidden." ${ }^{55}$ Therefore, a requirement of discriminatory motives was not adopted.

The effect of adopting a highly restrictive construction of the UNCG is the same as if every Soviet amendment had been accepted. But this frustrates the intent of the other delegates, who intended the UNCG to apply to other motives and contexts.

\section{Does the UNCG Require Physical or Biological Destruction?}

The total genocide interpretation of the UNCG equates intent to destroy with physical destruction. ${ }^{56}$ Some scholars have argued that genocide was not committed in Darfur because the state did not achieve "the intentional physical destruction of an ethnic group." 57 Some have also argued that the Cambodian Genocide did not occur because Cambodians are not a protected national group, and religious minorities were singled out for assimilation rather than murder. ${ }^{58}$ According to this interpretation, the UN General Assembly, Cambodian war crimes tribunal, and US Congress were simply being "idiosyncratic" or "political" in declaring a Cambodian genocide..$^{59}$ A similar argument is made about Kosovo, often while refusing to note that in 1999 several leaders of the key states involved in the drafting of the UNCG condemned genocide in Kosovo. ${ }^{60}$

Furthermore, some scholars condemned the International Criminal Tribunal for the former Yugoslavia (ICTY) for ruling that genocide was committed at Srebrenica as a result of the massacre of up to 8,000 Bosnian Muslim men and boys. Schabas, for example, argues because genocide must be physical, it "distort[s]" the UNCG to find, as the tribunal has, that genocide could be committed by massacring the men and boys of a community in order to make its physical survival in the area difficult or impossible. ${ }^{61}$ Another scholar remarks that because the Srebrenica massacre was improvised by the military, it lacked the element of political strategy to exterminate a race required to apply the stigma of genocide. ${ }^{62}$

There is extensive evidence in the text of the treaty and in the travaux préparatoires, however, that the drafters intended to prohibit non-physical genocides as well. The text of the UNCG refers to "mental harm" and to the forced removal of children from their parents' influence not as crimes against humanity but as acts of genocide. The word "physical" is used to qualify only one of the listed acts-the imposition of living conditions calculated to bring about the group's destruction..$^{63}$ The intent to destroy, therefore, need not be physical when the act does not kill. ${ }^{64}$

The drafting history of the UNCG reveals that the Soviet Union proposed another amendment limiting the intent to destroy a group to acts "aimed at the physical destruction" of the group, which was rejected. ${ }^{65}$ The Soviet Union argued that because "article II was concerned with biological genocide," the "idea of 'physical destruction' should therefore be specified in the text of the definition" so as to distinguish it from cultural genocide. ${ }^{66}$ The other delegates spoke out against this proposal. One delegate remarked that "history gave examples of genocide where there had been no intent of physical destruction of the groups concerned," which would not constitute genocide under the Soviet amendment, such as when "the older members of a group had been killed and the younger ones converted by diverse means to an ideology different from their own." 67 The United States agreed, explaining that the intent to destroy need not be shown by the actual destruction of the group as a result of the perpetrators' acts. ${ }^{68}$ 
The Soviet amendment was overwhelmingly rejected by a vote of 36 to 11, with four abstentions. ${ }^{69}$

The Soviet Union also proposed that genocide requires a "physical destruction of [a] racial, national (or religious) group committed on racial, national (or religious) grounds" and not merely an intent to destroy a group in whole or in part. ${ }^{70}$ This amendment failed as well. ${ }^{71}$ Therefore, as one delegate opposing the Soviet proposals explained, genocide may occur under Article II even though "individual members of [the group] continued to live normally without having suffered physical harm."72 The mental genocide prong of Article II confirms this interpretation. ${ }^{73}$ It applies to all "inhumane . . . treatment" and "persecution" that targets a group and tends toward its mental destruction. ${ }^{74}$

When the Soviet Union attempted to make religious genocide a subset of national genocide, a coalition of states including Egypt, Greece, and Yugoslavia successfully organized the opposition to this amendment. They pointed to ethnic and religious cleansing between Hindus and Muslims in India and Pakistan, Jews and Muslims in Palestine, and Serbs and Croats in Yugoslavia and argued that such "genocides" should be prohibited. ${ }^{75}$ In none of these historical episodes was the group completely eradicated, so the "genocide" was partial, potentially covered by the "destroy . . . in part" language adopted by the drafters.

Some scholars argue that ethnic cleansing and cultural genocide were excluded from the UNCG when Article III of the original draft was stripped during the deliberations and when a Syrian amendment addressing forced displacement was rejected. ${ }^{76} \mathrm{~A}$ closer examination reveals, however, that these proposals were not rejected because the drafters wanted to immunize from prosecution as genocide the selective murder of the leaders or adult men of a group followed by the deportation or forcible assimilation of women or children. Quite the contrary is true. The problem with Article III was not that it prohibited cultural genocide but that it defined it so broadly as to include restrictions on the use of language (think of English-only education laws), the destruction or "dispersion" of documents or objects of cultural or historical value (think of urban development projects), and the "systematic destruction of books" (think of libraries weeding out collections). ${ }^{77}$ It was therefore too difficult to establish the limits of cultural genocide when it was defined to include the "use of the language of the group ... in schools" or "preventing the use of . . . museums, schools, historical monuments, or places of worship."78 Schabas remarks that the US and Canada led the opposition to "cultural genocide"; they actually opposed including "ethnical" (or cultural and linguistic) groups in the UNCG at all, but they lost this fight when ethnic groups were included alongside racial groups. ${ }^{79}$

Similarly, the Syrian proposal was extremely overbroad in including any "measures intended to oblige members of a group to abandon their homes" by intimidating them, which might apply to the construction of public works such as highways through formerly residential neighborhoods after use of the power of eminent domain to force residents to leave. ${ }^{80}$ All of the leaders of the countries joining the treaty could be prosecuted for becoming complicit in genocide by building highways. The government of India objected that "not even the threat of genocide" was required by the Syrian amendment. ${ }^{81}$ The Soviet Union argued that true compulsion to depart from one's home under a threat of genocide was already covered by the draft convention. ${ }^{82}$

The intent of the drafters not to immunize ethnic cleansing as practiced in the Ottoman Empire, or more recently in the former Yugoslavia, was absolutely clear. The 
drafters announced their design to prevent and punish ethnic cleansing when they accepted a Swedish amendment to add "ethnical"83 to the Soviet categories of national, racial, or religious genocide. They made this amendment expressly in order to clarify that the impact upon the "whole of the traditions of a group, with its cultural and historical heritage, had to be taken into account." 84 Sweden emphasized that in some cases a group's language rather than its race would be the target of attacks. ${ }^{85}$ Sweden also argued that the law of genocide should protect "a group which was held together by a common origin or common identity." 86 It was understood that the Swedish amendment would apply to instances such as the post-World War II ethnic cleansing of the Germans in Poland and the Poles in Germany. ${ }^{87}$ Sweden argued that such groups "might be defined by the whole of [their] traditions and [their] cultural heritage." 88 The US and the Soviet Union also agreed that the UNCG should apply to the members of political groups who make up the intellectual or cultural leaders of populations that an occupying army like that of the Nazis was attempting to "subjugate." 89 A Greek amendment designed to prevent genocide by the forced abduction of children to be raised in new families, as occurred in the Ottoman Empire, also passed. ${ }^{90}$

The drafters made other departures from the model of physical genocide as in the case of the Jews gassed at Auschwitz. They dismissed a proposal to limit mental harm to "mutilations and biological experiments." 11 The US argued that physical injury not resulting in permanent harm or mutilations should be protected against. ${ }^{92}$ The drafters similarly expanded a predicate act of genocide from the impairment of the "physical integrity" of group members to the infliction of serious bodily or mental harm upon them. ${ }^{93}$ China explained that outlawing genocide was of cardinal importance to China because the Japanese had committed genocide in China by various methods, such as by dealing opium..$^{94}$ Japan has yet to ratify the UNCG. ${ }^{95}$

The text and drafting history clarify that genocide may occur by "deliberately inflicting on the group conditions of life calculated to bring about its physical destruction in whole or in part" ${ }^{\prime 96}$ with the intent to destroy the group in whole or in part, even when total destruction does not result. This prong of Article II actually summarizes a longer list of acts identified by the UN Secretary-General as causing slow death or impairment to a group's health, such as denial of food, medical care, hygiene, clothing, or housing and compulsion to perform excessive physical work. ${ }^{97}$ The SecretaryGeneral suggested that what is now called ethnic cleansing might inflict conditions of life calculated to destroy the group in part when it results in the denial of group members' livelihoods, confiscation of their homes and means of sheltering their children, mass dismissals from employment, and the refusal of food or other supplies needed for families to survive. ${ }^{98}$ Schabas also concedes that the drafters of the UNCG considered the Armenian Genocide, in which mass deportations resulted in deaths from hunger and exposure and were accompanied by direct massacres, as the paradigm of indirect genocide using the forces of nature. ${ }^{99}$ But he argues that the UNCG is not applicable to the Armenian Genocide because Armenians suffered only cultural harm in the period since genocide entered customary international law sometime after $1914 .{ }^{100}$

In light of this drafting history, the German Supreme Court has found that genocide was committed in Bosnia and Herzegovina because "cleansing" occurred by "killings, ... a determined effort to capture others for killing, the forced transportation or exile of the remaining population, and the destruction of homes and places of worship." 101 The fact that some victims in Bosnia and Herzegovina were deported or exiled 
did not preclude a conviction for genocide. Similarly, the US Supreme Court let stand a federal appeals court's ruling which concluded that genocide occurred in Bosnia even prior to Srebrenica. ${ }^{102}$ Courts in Austria, Brazil, Cambodia, Equatorial Guinea, Ethiopia, Latvia, Lithuania, Iraq, Spain, and Ukraine have also confirmed that the UNCG was not intended to be applied narrowly so as to be triggered only when a plan or policy to destroy an entire group is decided upon at the heights of state power. They have found defendants culpable for genocide based on localized massacres and forcible displacement of the remaining population. ${ }^{103}$ National courts have ruled that massacres affecting as few as 12 members of a group could reflect genocidal intent. ${ }^{104}$ Based on this reading, leaders of states party to the UNCG have laid genocide charges at the diplomatic or political level after massacres in which most of the group survived, as in Biafra in 1968, Bangladesh in 1971, Cyprus in 1974, Afghanistan in the 1980s, Iraq in 1984 and 1987-1991, Bosnia in the early 1990s, and Kosovo in the late 1990s. ${ }^{105}$ Such charges amount to state practice of genocide.

Other sources of the customary international law of genocide are to similar effect. These sources include General Assembly resolutions, the practice of domestic parliaments, the proclamations of national politicians and diplomats, the reports of UN experts, and the treatises of jurists and international law scholars. ${ }^{106}$ The international community has simply refused to restrict the crime of genocide to total unprovoked genocides based on state policy. A number of General Assembly resolutions recognize ethnic cleansing as a form of genocide. ${ }^{107}$ Many, perhaps most, of the delegates to the drafting process of the UNCG described ethnic cleansing (including the ethnic cleansing conducted by the Soviet Union) as genocide. ${ }^{108}$ The Pakistani delegate called cultural genocide indivisible from physical genocide under Article II. ${ }^{109}$ The representatives of several other states agreed that when accompanied by violence, cultural genocide should be prohibited by the UNCG. ${ }^{110}$ Numerous treatise writers make similar arguments. ${ }^{11}$ Turkey and other countries that have ratified the UNCG have protected cultural and political groups from genocide and have often condemned ethnic cleansing as genocide. ${ }^{12}$

Schabas has argued that the ICC, the ICJ, and the ICID are in agreement with him that ethnic cleansing is irreconcilable with an intent to destroy a group in whole or in part. ${ }^{113}$ It is unfortunately true that the ICJ, following Schabas's lead, concluded in 2007 that the drafting history of the UNCG excludes destruction of the group through displacement alone and includes only "biological" and "physical" destruction. ${ }^{114}$ However, the ICJ indicated that ethnic cleansing may constitute genocide when it rises to the level of "deliberately inflicting on the group conditions of life calculated to bring about its physical destruction in whole or in part" without persuasively analyzing whether this was the case in Bosnia and Herzegovina. ${ }^{115}$ The Pre-Trial Chamber I of the ICC initially agreed with the ICJ, but the decision was reversed on appeal to the ICC's appellate body. ${ }^{116}$ The Pre-Trial Chamber I rejected a charge of genocide after concluding that the government of Sudan may have "subjected, throughout the Darfur region, thousands of civilians, belonging primarily to the Fur, Masalit and Zaghawa groups, to acts of murder and extermination." 117 The ICID report adopted a similarly pro-defendant construction of the UNCG when it determined that even though the UNCG was originally intended to protect groups against the destruction of a substantial number of their members, the destruction of a substantial number of Fur and Masalit people did not qualify as genocide. ${ }^{118}$ 
The international criminal tribunals have often agreed with the Appeals Chamber of the ICC that deportation could constitute genocide and disagreed with its Pre-Trial Chamber I and the ICID report on that point. The ICTY has twice ruled that survivors of selective killings might suffer mental genocide because they fear that they might be killed or injured. ${ }^{119}$ The ICTY's decision on the indictment against Radovan Karadzić and Ratko Mladić stated "that cruel treatment, torture, rape and deportation could constitute serious bodily or mental harm done to members of a group under a count of genocide." 20 The ICTY has found "that the forcible transfer of individuals could lead to the material destruction of the group, since the group ceases to exist as a group, or at least as the group it was." ${ }^{21}$ It has also confirmed three times "that the means of deliberately inflicting on the group conditions of life calculated to bring about its physical destruction, in whole or in part, include subjecting a group of people to a subsistence diet, systematic expulsion from their homes and deprivation of essential medical supplies below a minimum vital standard." 122 Although some defendants accused of genocide by ethnic cleansing in Bosnia and Herzegovina were acquitted, these perpetrators spared from harm most of the civilians under their area of effective control and did not even deport most of them. ${ }^{123}$

The judgment in the trial of the mastermind of the Rwandan Genocide, Théoneste Bagosora, also indicates that the impossible standard of proof advocated by the ICJ was not applied. Although rejecting the prosecution's theory of a military-led conspiracy to commit genocide in Rwanda against all Tutsi, even those who were not suspected of sympathizing with the rebellion, the International Criminal Tribunal for Rwanda (ICTR) in 2008 convicted several military defendants of genocide for carrying out selective massacres of Tutsi in Kigali as well as in other places, including a church, a mosque, and a university. ${ }^{124}$ Other ICTR convictions largely inferred genocidal intent without requiring smoking-gun evidence of a state policy of genocide; the judges look for evidence of large-scale atrocities, systematic ethnic targeting, the use of derogatory ethnic language or slurs, and the large scale of the attempted destruction of those who survived. ${ }^{125}$

\section{Does the UNCG Only Prohibit a Plan or Policy of Genocide?}

In 2005, the ICID concluded that the government of Sudan had not pursued a policy of genocide despite many massacres, mass rapes, deportations, burnings of villages, destruction of foodstuffs, and so forth. ${ }^{126}$ The report, according to some scholars, demonstrated that a "state plan or policy" is an "essential element" of the crime of genocide even if it was "unspoken" by the UNCG's drafters. ${ }^{127}$ In 2007, for example, Schabas defended the "theoretical construction" of genocide adopted by the ICJ, under which ethnic cleansing does not constitute genocide because it does not reflect a plan or policy of total destruction. ${ }^{128}$

The text of the UNCG clearly does not require a plan or policy of genocide by the state or its rulers. ${ }^{129}$ Instead, Article IV of the UNCG makes it clear that private individuals who are not public officials may commit genocide. ${ }^{130}$

During the drafting process, the US and other nations blocked a proposed requirement for government officials to "co-operate" in genocide because these nations intended the UNCG to "afford protection to human groups against the acts of individuals."131 Likewise, a proposed requirement of "deliberate" acts prompted opposition because "premeditation had a special meaning, distinct from that of intention." 132 The "intent to destroy" requirement represented a liberalization of the Secretary-General's draft, which required a "purpose of destroying." 133 The Secretary-General apparently designed the 
purposeful genocide requirement to ensure that the "act must be deliberate," as opposed to "isolated acts of violence not aimed at the destruction of a group of human beings." 134 Therefore, the phrase "deliberate acts" became "acts" in the definition of genocidal intent, and the proposed requirement that officials "co-operate" in the killing was dropped. ${ }^{135}$

The delegates' rejection of a requirement of racist motive or premeditation is important because in common law the notion of intent or specific intent may be inferred from conduct. Courts infer specific intent to kill in domestic US law from the destructive nature of an act, such as shooting another person. ${ }^{136}$ The international criminal tribunals, with many judges trained in the civil law tradition, have similarly inferred intent from the act and the surrounding circumstances. ${ }^{137}$ Otherwise, only a confession could convict. ${ }^{138}$

In response to a French amendment that would require the participation or "connivance" of constitutional rulers in genocide, the drafters expressed widespread opposition to such a definition. Like scholars endorsing a "plan or policy" element for the crime of genocide, France wanted to "define genocide in terms of its essential and primary character as a governmental crime." 139 The US delegate, on the other hand, declared that the killing of even one individual with the intent to destroy a group could be genocide. ${ }^{140}$ The US desired to preserve state responsibility for genocide in instances "where an act of genocide had been committed by private individuals without any participation by the rulers, if those rulers had not taken appropriate measures to punish the guilty persons." ${ }^{41}$ The UK delegate explained that "acts of genocide committed, encouraged or tolerated by rulers were not the only cases of genocide." 142 The delegates of Iran and Pakistan likewise objected because under the amendment the massacres of religious groups recently committed in India would not be covered and insisted that such "fascist or terrorist organizations" should be punished regardless of the degree of participation of the state. ${ }^{143}$ The Egyptian delegate made similar comments about recent massacres in Palestine. ${ }^{144}$ Brazil's delegate explained that "cultural genocide" could "obviously be committed by private individuals without any responsibility on the part of the State." 145 Yugoslavia's delegate mentioned an incident in which war criminals illegally entered Yugoslavia with plans to commit crimes of genocide. ${ }^{146}$ The French amendment received only 2 votes in favor, 40 against, and 1 abstention. ${ }^{147}$

One issue that judges have with resort to the legislative history of statutes or treaties is that the process can be somewhat selective, with text, history, and case law providing ample opportunity to reach nearly any conclusion. ${ }^{148}$ In this vein, advocates of the most restrictive construction of the UNCG have no trouble disregarding the drafting history of the UNCG when the history indicates a broad meaning. Thus, for example, while acknowledging that the drafting history of the UNCG reflects a clear rejection of a requirement of a genocidal plan or policy, Schabas has argued that it is impossible to imagine genocide without it. He persisted in this view even after several judges of international criminal tribunals disagreed with him. ${ }^{49}$ Finally, when some other judges (notably within the ICTY) and the Darfur commission agreed with him, he looked to their rulings as authoritative, despite criticizing rulings by judges over the years as contradicting the drafting history. ${ }^{150}$ When both judges and the drafting history repudiated his narrow reading of the UNCG, he appealed to public policy. ${ }^{151}$ The gist of this policy argument is that a generous interpretation of the UNCG "demeans the suffering of the victims"; how the survivors of massacres in Rwanda are demeaned by genocide prevention is not explained, and indeed the notion is denied by survivors themselves. ${ }^{152}$ 


\section{Was State Responsibility for Genocide Intended to Be Prospective Only?}

Some scholars have argued that the UNCG is inapplicable to the Armenian Genocide, either because of insufficient deaths or because the only acts that occurred between the 1920s and 1940s, when the customary international law crime of genocide might have come into existence, involved the destruction of cultural, historical, and religious heritage, to which the UNCG does not apply. ${ }^{153}$ Schabas, for example, has argued that scholars on the Armenian Genocide "overstate the law" in order to "play well in certain Armenian communities," implicitly accusing them of twisting the law to earn funds or gain popularity in the Armenian Diaspora. ${ }^{154} \mathrm{He}$ insisted repeatedly that Turkey has no responsibility for the Armenian Genocide, even though Germany and German officials had to take responsibility for a genocide completed before the UNCG was drafted. ${ }^{155}$

The typical analysis of the retrospective application of the UNCG has several defects. First, it assumes that statutes of limitation on genocide may only be relaxed in the case of an ongoing genocide. ${ }^{156}$ Second, it assumes that Germany's payment of reparations to the State of Israel and individual Jews was strictly voluntary. ${ }^{157}$ Third, it assumes that international law will not make any progress in the next century toward redressing instances of mass violence that occurred in the distant past. ${ }^{158}$

Case law arising out of the US casts doubt on these assumptions. First, at least one court has held that statutes of limitation should not apply to crimes against humanity concluded decades ago, such as during the Vietnam War. ${ }^{159}$ The court noted that the "principle of non-applicability of statutory limitations" to crimes against humanity, including genocide, is recognized in international treaties including the Rome Statute of the ICC and the Convention on the Non-Applicability of Statutory Limitations to War Crimes and Crimes Against Humanity. ${ }^{160}$ The latter convention reflects customary international law enforceable in the US, according to some scholars. ${ }^{161}$ Second, US courts have confirmed that plaintiffs' attorneys' threats of litigation compelled Germany to come to the table with various other entities and announce a scheme to compensate survivors of the Nazi era for the actions of Germany's war industry. ${ }^{162}$ Prior to that, the victims of Nazis received compensation, ${ }^{163}$ including by such means as the seizure of assets by the Allies and their distribution to Jews and other survivors of Nazi crimes. ${ }^{164}$ Even before the UNCG was drafted, the occupying powers in Germany established General Claims Laws to distribute gold, diamonds, and fine art to Jews and other victims. ${ }^{165}$ Third, in 2006, the State of California extended the statute of limitations for Armenian Genocide survivors until 2010 to $2016 .{ }^{166}$ The law marches on.

\section{Do Genocide Scholars Have a Responsibility to Past and Future Victims of Genocide?}

Roger Smith, Erik Markusen, and Robert Jay Lifton have argued that genocide scholars have a professional responsibility not to give too much analytical aid to the defenders of genocidal acts. ${ }^{167}$ With Charny, they maintained that genocide denial may be an assault on the cultural identity and national existence of the victim group. ${ }^{168}$ The destruction of the remembrance of the act increases the likelihood of a recurrence. ${ }^{169}$ Denial leads to a "situation of impunity," which "fosters the chronic repetition of human rights violations and the total defenselessness of the victims and their next of kin." ${ }^{170}$ As others have argued with respect to torture, lawyers might embolden perpetrators. ${ }^{171}$

The "definitionalist" position that partial, cultural, ethnic, or religious genocide is not a violation of the UNCG, and that the UNCG should not be modified upon its enactment in domestic penal codes to include such non-racial groups, threatens to 
exonerate those accused of past genocide and to embolden the perpetrators of future genocides. The position is a popular one in Turkey, Russia, China, Sudan, Yugoslavia, and other places where past or present leaders have been charged with genocide by human rights advocates. ${ }^{172}$ As a Turkish diplomat summarized the definitionalist perspective in the Turkish Daily News, murders or rapes targeting a group such as the Armenians are genocidal only if "committed on a collective scale with a racist motive leading to the formation of the intent to destroy the group 'as such"' or if committed "with the intent to destroy, which is motivated by racial hatred."173 The author argued that the Armenians were solely a "political group" despite their ethnic and religious differences, and "no anti-Armenian racism existed." 174 On a related note, Schabas cited a rumor that a Russian official agreed with him that genocide could not have been committed in Darfur for then it might have been committed in Chechnya as well. ${ }^{175}$ Furthermore, China resisted the Security Council's application of the word "genocide" to the atrocities perpetrated in Rwanda in 1994; at least one expert cites "the Tibet factor" because China might have had "Taiwan or Tibet in mind."176 The Sudanese government smugly embraced the ICID report's adoption of the theory of genocide as total destruction in January 2005. ${ }^{177}$ Tellingly, British attorneys hired by two organizations supporting the Sudanese government and working in coordination with Sudanese officials urged the ICC to read Schabas's works and find that "grave crimes have been committed in Darfur by all parties to the conflict" but not genocide. ${ }^{178}$ Finally, it is worth noting that several defendants accused of genocide in Yugoslavia offered Schabas's expert report that did not find genocide to have been committed, a report which the tribunal found to be an improper attempt to usurp the law-finding function of the tribunal's own judges ${ }^{179}$ Radovan Karadžić expressed hope in his pre-trial brief that Schabas's work would exonerate him on the grounds of lack of intent. ${ }^{180}$

Part of the problem is that arguments against applying the concept of genocide to partial genocides usually rest on the denial of the magnitude of the events themselves. Thus, writers in the total genocide tradition of scholarship have ignored the true scale of death during episodes of mass violence. Regarding the Armenian Genocide, Schabas basically denied it on grounds of inadequate destruction in the period since genocide entered customary international law, which was sometime between 1914 and 1939. ${ }^{181}$ He argued that only property was subject to ongoing destruction even though in reality countless thousands of Armenians must have died prematurely and/or suffered serious mental harm as a result of poverty or ill-health since the 1920s, and he dismissed claims that the continuous destruction of Armenian monuments reflects an ongoing intention to destroy Armenia. ${ }^{182}$ In his view, the only recognition appropriate for the Armenian Genocide, like the Cambodian one, would be a political, not a legal, one. ${ }^{183}$

Schabas also characterized the Cambodian Genocide as not meeting a rigorous definition of genocide because "destruction of religious institutions and forced assimilation of populations are acts of cultural, not physical, genocide." ${ }^{184}$ Yet he failed to offer a death toll of Cambodians under the Khmer Rouge or to apply Article II(c) of the UNCG, which refers to "deliberately inflicting on the group conditions of life calculated to bring about its physical destruction in whole or in part." ${ }^{185}$ Nor did he discuss Articles II(d) or II(e) in this context, which refer to "imposing measures intended to prevent births within the group" and "forcibly transferring children of the group to another group." 186 The Khmer Rouge forcibly sterilized women and stole children from their parents in order to destroy families and work children to death. ${ }^{187}$ Ben Kiernan and 
others have shown that the Buddhist, Vietnamese, and Muslim populations of Cambodia were not simply assimilated; they were massacred and tortured. ${ }^{188}$ The post-Khmer Rouge government announced that 1,800 Buddhist monks and 41,000 Muslims were killed or died from Khmer Rouge policies in Phnom Penh from 1975 to $1979 .{ }^{189}$ None of Schabas's works provided any evidence that the death toll among Tutsi in Kigali was higher than that, even though he refers to Tutsi as victims of a clear genocide. ${ }^{190}$

There are similar flaws with scholarly analyses of genocide charges relating to Bosnia and Herzegovina, Kosovo, and Darfur. Writing on Bosnia/Herzegovina and Kosovo, some scholars fail to acknowledge that scientific studies suggest that estimates of excess deaths vary between 200,000 and 305,000 for Bosnia/Herzegovina and between 12,000 and 18,300 for Kosovo. ${ }^{191}$ Scholars have argued, moreover, that only "men of military age" were killed at Srebrenica, ${ }^{192}$ whereas evidence showed that younger boys were also killed. ${ }^{193}$ With respect to Darfur, scholars have often failed to acknowledge a death toll of 70,000 in 2004 , rising to 400,000 in $2006,{ }^{194}$ or have described the events as massacres of the "military-aged men" and displacement of the civilian population, ${ }^{195}$ when in fact many children, women, and elderly people have been massacred as well, even according to the deeply flawed ICID report. ${ }^{196}$ These omissions of death tolls widely cited by others are central to some total-genocide scholars' argument that deportation is a humane, protective policy. ${ }^{197}$

\section{Restoring the Legal Force of the UNCG}

Advocates of a pro-defendant construction of the UNCG argue that it will not result in an "impunity gap" for perpetrators of genocide by selective massacres or the imposition of poor living conditions. ${ }^{198}$ The theory is that crimes against humanity will cover these acts.

However, there is no counterpart to Article I of the UNCG which establishes an obligation to prevent and punish all crimes against humanity. ${ }^{199}$ Crimes against humanity have been committed in nearly every conflict since World War II, and international criminal tribunals have not been forthcoming in punishing the perpetrators, especially in the Baltic states, the Koreas, Tibet, Southeast Asia, Indonesia, Afghanistan, Chechnya, Lebanon, Israel, Palestine, India, Pakistan, Bangladesh, Sri Lanka, British Kenya, Burundi, the Congo, Nigeria, Rhodesia, Angola, Mozambique, South Africa, Peru, Colombia, and Mexico. Even when a hybrid tribunal has convened, as with the Special Panels and Serious Crimes Unit for East Timor, the result has often made a mockery of justice. ${ }^{200}$

Some scholars have suggested that no one cares and have implied that nothing should be done when a single individual kills or maims many others with the intent to destroy an entire group. ${ }^{201}$ It would "trivialize" the UNCG to punish an ethnic or religious massacre by such a person, is the suggestion. ${ }^{202}$ When the US was convinced that the events in Rwanda were simply local "acts of genocide" without a total physical genocide, the State Department took the view that the US would not be obligated to punish the perpetrators or prevent the acts. ${ }^{203}$

The narrow definition of genocide popularized by scholars and adopted by the ICJ deprives the UNCG of most of its legal force because few or none of the mass atrocities since 1948 qualify as genocide. ${ }^{204}$ With the ICTR's judgment in the Bagosora case, even Rwanda could be doubted to be a total racial genocide. ${ }^{205}$ In the case of Darfur, Professor Gérard Prunier observed that the public's "mass-consumption need for brands and labels" means that "a genocide is more serious[,] a great tragedy and more deserving of 
our attention than [the deaths] of 250,000 people in non-genocidal massacres."206 Rwanda, Yugoslavia, Iraq, and Sudan probably had to be "branded" as anti-minority genocides before anything could be done; indeed, massive crimes against humanity against the dominant ethnic groups in these countries went unpunished by the UN system. ${ }^{207}$ The insistence on the original understanding of the UNCG contributed to action on Darfur.

In adopting the total genocide model of the UNCG, the ICJ, ICC Pre-Trial Chamber I, and ICID report created an "almost impossible standard of proof” for establishing genocidal specific intent. ${ }^{208}$ As Eric Reeves has argued, it seems that they were attempting to ensure "the irrelevance of the Genocide Convention." 209 Only the rejection of this model and a return to first principles can ensure the UNCG's effectiveness.

Likewise, adding a "plan or policy" of genocide as an element of the crime results in nearly impassable barriers to the enforcement of the UNCG. The actual killers during genocides would usually be acquitted on the basis that they were not aware of the total extermination scheme decided by the political or military leadership. ${ }^{210}$ The leaders would often then be acquitted for not committing the genocidal acts themselves. ${ }^{211}$ It is a perfect recipe for impunity.

The drafters of the UNCG predicted that impunity would result if the definition of genocide were to be made very narrow. During the debate on the French amendment requiring the participation of rulers in genocide, the Venezuelan delegate argued that "fear of punishment would be diminished in the case of non-rulers, while rulers themselves would frequently be able to escape punishment, either by avoiding trial by all possible methods or by shaking off responsibility by making false accusations." 212 The Soviet Union remarked that a definition based on a state policy would "free the large majority of those who had committed acts of genocide from all responsibility and ... give rulers an opportunity to avoid punishment by alleging that the crimes of which they had been accused had been committed in circumstances beyond their control." 213 This is, of course, occurring now with respect to Cambodia, Darfur, Iraq, Rwanda, and Yugoslavia.

\section{Conclusion}

Genocide research is at an ethical and legal turning point. The question it faces is, Will excessively pro-defendant interpretations of the UNCG make it inapplicable to the mass murders of the twenty-first century? And, in so doing, will scholars belittle the full scale of post-World War II genocides in order to classify them as war crimes or "tragedies"?

The drafters of the UNCG have left us a precious legacy. After centuries of crimes by heads of state, the efforts of Lemkin and others created a framework to prevent and punish such atrocities. The UNCG they handed down to us is a flexible and forwardlooking instrument, stripped of the limiting references to Nazism and fascism that the Soviet Union would have liked to use to bind judges and prosecutors to the past.

The UNCG is a promise to all the peoples of the world that by common resolve humanity will halt not only racial annihilation by poison gas or mass grave but also other methods of targeting human groups for total or partial destruction. Genocide scholars have the solemn responsibility of transmitting the hope and determination conveyed by this promise to future generations. They must not forget that the UNCG was drafted to predict and pre-empt new forms of genocide. 
Hannibal Travis is Associate Professor of Law at Florida International University. He has published Genocide in the Middle East: The Ottoman Empire, Iraq and Sudan (Carolina Academic Press, 2010) and contributions to The Top Ten Global Justice Law Review Articles, 2008 (Oxford University Press, 2009) and Forgotten Genocides (University of Pennsylvania Press, 2011).

\section{Notes}

1. U.N. Doc. No. A/RES/47/121 (18 Dec 1992); U.N. Doc. No. A/RES/48/153 (20 Dec 1993); U.N. Doc. No. A/RES/49/205 (23 Dec 1994); U.N. Doc. No. A/RES/50/192 (22 Dec 1995); U.N. Doc. No. A/RES/ 51/115 (12 Dec 1996); U.N. Doc. No. E/CN.4/1997/57 (21 Feb 1997); U.N. Doc. No. A/RES/52/135 (27 Feb 1998).

2. John Barron, Murder of a Gentle Land: The Untold Story of Communist Genocide in Cambodia (New York: Reader's Digest Press, 1977); René Lemarchand, “Ethnic Genocide,” Society 12,2 (1975): 50-60.

3. See, e.g., Leo Kuper, Genocide: Its Political Uses in the Twentieth Century (London: Penguin, 1981); Israel W. Charny, ed., Genocide: A Critical Bibliographic Review, vol. 1, Genocide: A Critical Bibliographic Review (New York: Facts on File, 1988); Israel W. Charny, ed., Genocide: A Critical Bibliographic Review, vol. 3, The Widening Circle of Genocide (New Brunswick, NJ: Transaction, 1994).

4. Richard Hovannisian, The Armenian Genocide in Perspective (New Brunswick, NJ: Transaction, 1986); Richard Hovannisian, The Armenian Genocide: History, Politics, Ethics (New York: St. Martin's, 1992); Richard Hovannisian, The Armenian Genocide: Cultural and Ethical Legacies (New Brunswick, NJ: Transaction, 2007); Vahakn Dadrian, "Genocide as a Problem of National and International Law: The World War I Armenian Case and its Contemporary Legal Ramifications," Yale Journal of International Law 14,2 (1989): 221-334; Vahakn Dadrian, The History of the Armenian Genocide. Ethnic Conflict from the Balkans to Anatolia to the Caucasus (Providence: Berghahn Books, 1995); Vahakn Dadrian, "The Historical and Legal Interconnections between the Armenian Genocide and the Jewish Holocaust: From Impunity to Retributive Justice," Yale Journal of International Law 23,2 (1998): 503-59. For more recent scholarship in this area, see Taner Akçam, A Shameful Act: The Armenian Genocide and the Question of Turkish Responsibility (New York: Metropolitan, 2006); Taner Akçam and Vahakn Dadrian, Judgment at Istanbul: The Armenian Genocide Trials (New York: Berghahn Books, 2011).

5. Thea Halo, Not Even My Name (New York: Macmillan, 2001); Donald Bloxham, The Great Game of Genocide: Imperialism, Nationalism, and the Destruction of the Ottoman Armenians (Oxford: Oxford UP, 2005), 97-8; Adam Jones, Genocide: A Comprehensive Introduction, 2nd ed. (London: Routledge, 2010), 150-72.

6. Frank Chalk and Kurt Jonassohn, The History and Sociology of Genocide: Analyses and Case Studies (New Haven, CT: Yale UP, 1990); Helen Fein, “Accounting for Genocide after 1945: Theories and Some Findings," International Journal on Minority and Group Rights 1,2 (1993): 79-106; Helen Fein, Human Rights and Wrongs: Slavery, Terror, Genocide (Boulder, CO: Paradigm, 2007); Rummel, Death by Government; Iris Chang, The Rape of Nanking (New York: Basic Books, 1997); Power, "A Problem from Hell"; Kiernan, Blood and Soil; Ben Kiernan, The Pol Pot Regime: Race, Power, and Genocide in Cambodia Under the Khmer Rouge, 1975-1979 (New Haven, CT: Yale UP, 2002); Samuel Totten, ed., Genocide: A Critical Bibliographic Review, vol. 5, Genocide at the Millennium (New Brunswick, NJ: Transaction, 2005); Samuel Totten and Robert Hitchcock, eds., Genocide: A Critical Bibliographic Review, vol. 8, Genocide of Indigenous Peoples (New Brunswick, NJ: Transaction, 2010).

7. Raphael Lemkin, "Genocide," American Scholar 15,2 (1946): 227-30.

8. France v. Goering, Trial of the Major War Criminals before the International Military Tribunal, Nuremberg, 19 IMT 531 (29 Jul 1946), 497; William Schabas, Genocide in International Law: The "Crime of Crimes" (Cambridge: Cambridge UP, 2000), 38; Steven L. Jacobs, ed., Raphael Lemkin's Thoughts on Nazi Genocide: Not Guilty? (Lewiston: Edwin Mellon, 1992), 171, quoted in Dan Stone, "Raphael Lemkin on the Holocaust," Journal of Genocide Research 7,4 (2005): 539-50, 539, 544; William Schabas, "Origins of the Genocide Convention: From Nuremberg to Paris," Case Western Reserve Journal of International Law 40,35 (2008): 35-47, 42.

9. Raphael Lemkin, Axis Rule in Occupied Europe: Laws of Occupation, Analysis of Government, Proposals for Redress (Washington, DC: Carnegie Endowment for International Peace, 1944), xi-xii.

10. Associated Press, "U.N. Is Asked to Indict Russia for Crushing Religious Groups," The Montreal Gazette, 19 Jan 1953, 9.

11. See generally Edward M. Kennedy, "Biafra, Bengal, and Beyond: International Responsibility and Genocidal Conflict: Remarks [Comments]," American Society of International Law Proceedings 66 (1972): 89-90; R.J. Rummel, Death by Government: Genocide and Mass Murder Since 1900 (New Brunswick, NJ: Transaction, 1994), 79-109, 298-99, 310-128; Samantha Power, "A Problem from 
Hell': America and the Age of Genocide (New York: Basic Books, 2002), 171-246; Dictionary of Genocide: A-L, ed. Samuel Totten, Paul Robert Bartrop, and Steven L. Jacobs (Santa Barbara, CA: ABCCLIO, 2008), 13-14, 58-59, 205, 154, 252; Ben Kiernan, Blood and Soil: Genocide and Extermination in World History from Sparta to Darfur (New Haven, CT: Yale UP, 2007), 366, 541-65.

12. See S.C. Res. 827 (citing recommendation of Co-Chairmen of Steering Committee of the International Conference on the Former Yugoslavia, 25 May 1993); S.C. Res. 955 (citing Commission of Experts on Rwanda established pursuant to resolution 935 and Report of Professor René Degni-Ségui, the Special Rapporteur for Rwanda of the U.N. Commission on Human Rights, S/1994/1157, annex I and annex II, 8 Nov 1994); S.C. Res. 780, Commission of Experts on War Crimes in former Yugoslavia (6 Oct 1992); S/25274, Interim Report of the Commission of Experts Established Pursuant to Security Council Resolution 780 (1992; 11 Feb 1993); A/47/747, "The Situation in Bosnia and Herzegovina," Report of the Secretary-General (3 Dec 1992), gg 23-30; S/1994/1405 (Annex), Final Report of the Commission of Experts on Rwanda (9 Dec 1994); M. Cherif Bassiouni, "From Versailles to Rwanda in 75 Years: The Need to Establish a Permanent International Criminal Court," Harvard Human Rights Journal, 10 (1997): 11-62, 11; Letter from Holocaust Scholars to the ICC, 15 Sept 2008, http://www.thecuttingedgenews.com/index.php?article=773 (accessed 15 Dec 2011); "Leading Holocaust Scholars Back ICC Sudanese Genocide Case," Jerusalem Post, 15 Sept. 2008.

13. Prosecutor v. Akayesu, ICTR-96-40T, Trial Chamber, Judgment (2 Sept. 1998), gg 495, 501, 503, 521; Prosecutor v. Blagojević and Jokic, IT-02-60-T, Trial Chamber I, Judgment (17 Jan 2005), gg 657-665; Prosecutor v. Krstić, IT-98-33-A, Appeals Chamber, Judgment (19 Apr 2004), 57 (partial dissenting opinion of Judge Shahabudeen). See also David Nersessian, "The Contours of Genocidal Intent: Troubling Jurisprudence from the International Criminal Tribunals," Texas International Law Journal 37,2 (2002): 231-76, 269; William Schabas, review of The Genocide Convention: The Travaux Preparatoires, by Hirad Abtahi and Philippa Webb," American Journal of International Law 104,2 (2010): 318-19.

14. According to one scholar, a "very strict" interpretation of the UNCG means that it may virtually never be applied to actual massacres. Schabas, Genocide in International Law, 10, 544. According to a practitioner before the International Criminal Tribunal for the Former Yugoslavia, a narrow reading of the UNCG gives the "benefit of the doubt" to the offender. Cécile Tournaye, "Genocidal Intent before the ICTY," International and Comparative Law Quarterly 52,2 (2003): 447-57, 447, 454. According to an international criminal defense lawyer, the main issue is to "be creative in interpreting the test" for genocide and "try to narrow the test as much as one can, hoping that it will not fit on the defendant" because " $[\mathrm{m}]$ ost defendants deny any loathing for members of the other group or deny any personal involvement in attacking the other group." Mikhail Wladimiroff, "Defending Individuals Accused of Genocide," Case Western Reserve Journal of International Law 40,1/2 (2008):271-80, 278-79.

15. William Schabas, "Genocide, Crimes Against Humanity, and Darfur: The Commission of Inquiry's Findings on Genocide," Cardozo Law Review 27,4 (2006): 1703-21, 1703, 1719. For a different perspective vis-à-vis the findings/determination of the Commission of Inquiry on Darfur, see Eric Reeves, Report of the International Commission of Inquiry on Darfur: A Critical Analysis (Part I and Part II), 2 Feb 2005 and 6 Feb 2005, respectively, www.sudanreeves.org (accessed 15 Dec 2011); Samuel Totten, "The UN International Commission of Inquiry on Darfur: New and Disturbing Findings," Genocide Studies and Prevention 4,3 (2009): 354-78, http://dx.doi.org/10.3138/gsp.4.3.354.

16. Gündüz Aktan, "The Armenian Problem and International Law," in The Armenians in the Late Ottoman Period (Turkish Historical Society, 2001), 263-314, http://www.mfa.gov.tr/data/DISPOLITIKA/ ErmeniIddialari/Document.pdf (accessed 15 Dec 2011); Steven T. Katz, "The 'Unique' Intentionality of the Holocaust," Modern Judaism 1,2 (1981): 161-83, 164, 167-68, 170-71, 173-75; Schabas, review of Genocide Convention, 320, 323-25; William Schabas, "Genocide and the International Court of Justice: Finally, a Duty to Prevent the Crime of Crimes," Genocide Studies and Prevention 2,2 (2007): 101-22, 114, http://dx.doi.org/10.3138/gsp.2.2.101; Tournaye, "Genocidal Intent before the ICTY," 454.

17. William Schabas, "Problems of International Codification - Were the Atrocities in Cambodia and Kosovo Genocide?," New England Law Review 35,2 (2001): 287-302, 296, 301-2; William Schabas, "Was Genocide Committed in Bosnia and Herzegovina? First Judgments of the International Criminal Tribunal for the Former Yugoslavia," Fordham International Law Journal 25,1 (2001): 23-53, 45-47; William Schabas, "National Courts Finally Begin to Prosecute Genocide, the 'Crime of Crimes," Journal of International Criminal Justice 1,1 (2003): 39-63, 39, 41, 45, 55, 58; William Schabas, "The Jelisic Case and the Mens Rea of the Crime of Genocide," Leiden Journal of International Law 14,1 (2001): 125-39; William Schabas, "Genocide Law in a Time of Transition: Recent Developments in the Law of Genocide," Rutgers Law Review 61,1 (2008): 161-92, 164.

18. Schabas, Genocide in International Law, 102. 
19. William Schabas, "State Policy as an Element of International Crimes," Journal of Criminal Law and Criminology 98,3 (2008): 953-82, 970-71.

20. Donald Dutton, The Psychology of Genocide, Massacres, and Extreme Violence: Why "Normal" People Come to Commit Atrocities (Westport, CT: Praeger Security International, 2007), 17, 31; Daniel Greenfield, "The Crime of Complicity in Genocide: How the International Criminal Tribunals for Rwanda and Yugoslavia Got It Wrong, and Why It Matters," Journal of Criminal Law and Criminal Justice 98,3 (2008): 921-52, 934-35; Katz, "The 'Unique' Intentionality of the Holocaust," 175-8; David Marcus, "Famine Crimes in International Law,” American Journal of International Law 97, 2 (2003): 245-81, 245, 264-65.

21. Steven Katz, The Holocaust in Historical Context, vol. 1 (Oxford: Oxford UP, 1994), 24.

22. Liz McMillin, "The Uniqueness of the Holocaust," Chronicle of Higher Education, 22 Jun 1994, http:// chronicle.com/article/The-Uniqueness-of-the/90491/ (accessed 21 Feb 2012), quoted in David Stannard, "Uniqueness as Denial: The Politics of Genocide Scholarship," in Is the Holocaust Unique? Perspectives on Comparative Genocide, ed. Alan Rosenbloom (Boulder, CO: Westview, 2009). Katz similarly argues that the massacres of up to 200,000 Hutu in Burundi were merely "political" and therefore not genocidal. Cf. Katz, "The 'Unique' Intentionality of the Holocaust,” 176.

23. Steven Katz, "Uniqueness: The Historical Dimension," in Is the Holocaust Unique?, 69. See also Katz, "The 'Unique' Intentionality of the Holocaust," 174-75.

24. Schabas, "Was Genocide Committed in Bosnia and Herzegovina?" 45-47; William Schabas, "Darfur and the 'Odious Scourge': The Commission of Inquiry's Findings on Genocide," Leiden Journal of International Law 18 (2005): 871-85, 881; Schabas, "Darfur and Genocide," 1716; William Schabas, "Genocide and the International Court of Justice," 112-4.

25. Guenter Lewy, The Nazi Persecution of the Gypsies (Oxford: Oxford UP, 2000), 225-6.

26. Ibid.

27. Katz, "The 'Unique' Intentionality of the Holocaust," 167.

28. Guenter Lewy, "The First Genocide of the 20th Century? (Armenian Massacres, 1915-1916)," Commentary 120,5 (2005): 47-52. Lewy argues in particular that the "primary intent of the deportation order was undoubtedly not to eradicate an entire people" because "large Armenian communities of Constantinople, Smyrna, and Aleppo were spared deportation and, apart from tribulations that also afflicted the Muslim populations of these cities, survived the war largely intact." Lewy fails to note that the leaders of the Armenian community in Constantinople were systematically executed starting in April 1915, that Turkish soldiers set a large fire in Smyrna in 1922 to destroy the Armenian quarter, or that these soldiers went about hunting and killing Armenians in Smyrna. Halo, Not Even My Name, 121-22; Jones, Genocide, 154-66.

29. Guenter Lewy, The Armenian Massacres in Ottoman Turkey: A Disputed Genocide (Salt Lake City: U of Utah P, 2005), ix, 43, 53, 57, 62, 90, 150, 235-41, 245, 248, 251-3, 268. See also Guenter Lewy, "Revisiting the Armenian Genocide," Middle East Quarterly 12,4 (2005): http://www.meforum.org/748/revisiting-the-armenian-genocide (accessed 15 Dec 2011).

30. Katz, "The 'Unique' Intentionality of the Holocaust," 175-6.

31. Ibid.

32. Schabas, Genocide in International Law, 168.

33. William Schabas, "Justice, Democracy, and Impunity in Post-Genocide Rwanda: Searching for Solutions to Impossible Problems," Criminal Law Forum 7,3 (1996): 523-60, 523-4, 551. The charge was even raised but not definitively resolved in 1993 in Rapport de la commission internationale d'enquête sur les violations des droits de l'homme au Rwanda depuis le 1er octobre 1990 (7-21 janvier 1993), 4950. Schabas was one of the investigators for this commission.

34. Schabas, "Genocide, Crimes Against Humanity, and Darfur," 1707-8.

35. Convention on the Prevention and Punishment of the Crime of Genocide, 9 December 1948, 78 U.N.T.S. 277, Article II, http://www.preventgenocide.org/law/convention/text.htm (accessed 13 Feb 2012) [UNCG].

36. See Kuper, Genocide, 30-31; Power, A Problem from Hell, 54.

37. See Ad Hoc Committee on Genocide, Report of the Committee and Draft Convention, U.N. Doc. No. E/794 (13 Oct 1948), 13-15; Kuper, Genocide, 30-1.

38. Norway: Amendment to Article II of the Draft Convention (E/794), U.N. Doc. No. A/C.6/228 (12 Oct 1948).

39. Ad Hoc Committee on Genocide, Summary Records of Meetings, 21 Sept-10 Dec 1948, U.N. Doc. No. A/C.6/SR.73 (13 Oct 1948), 93.

40. Ibid.

41. Ibid., 94 .

42. Ibid., 91.

(C) 2012 Genocide Studies and Prevention 7, no. 1 doi:10.3138/gsp.7.1.30 
43. Ibid., 92.

44. U.N. Doc. No. A/C.6/SR.73 (13 Oct 1948), 93; France: Amendments to the Draft Convention, U.N. Doc. No. A/C.6/224 (8 Oct 1948); Nehemiah Robinson, The Genocide Convention: A Commentary (New York: World Jewish Congress, 1960), 62.

45. Lewy, The Nazi Persecution of the Gypsies, 226; Schabas, Genocide in International Law, 200. See also Schabas, "The Jelisic Case," 133; Schabas, "The Law and Genocide," in Bloxham and Moses, The Oxford Handbook of Genocide Studies, 138; Tournaye, "Genocidal Intent before the ICTY," 447, 459.

46. Antonio Cassese, "Flawed International Justice for Sudan," La Repubblica (15 Jul 2008), http://www. mediafire.com/?zyzjnofumlz (accessed 15 Dec 2011); Alexander De Waal, "Review of Gerard Prunier, Darfur: An Ambiguous Genocide," Contemporary Conflicts (1 Sept 2005), http://conconflicts.ssrc.org/ hornofafrica/ambiguous_genocide/(accessed 15 Dec 2011); Schabas, Genocide in International Law, 211-7, 248; Schabas, "State Policy as an Element of International Crimes," 970-2. See also Tournaye, "Genocidal Intent before the ICTY," 454, 459.

47. Schabas, Genocide in International Law, 303.

48. Ibid., 240, 244.

49. Barry Sautman, "Cultural Genocide in International Context," in Cultural Genocide and Asian State Peripheries, ed. Barry Sautman (New York: Macmillan, 2006) 8; Schabas, "Problems of International Codification," 296; William Schabas, "Ethnic Cleansing' and Genocide: Similarities and Distinctions," European Yearbook of Minority Issues 3 (2003/2004): 109-28, 123; William Schabas, "The International Legal Prohibition of Genocide Comes of Age," in Totten, Genocide at the Millennium, 169-84, 169, 177; Thomas W. Simon, The Laws of Genocide: Prescriptions for a Just World (Westport, CT: Greenwood, 2007), 37, 85-99. See also Gündüz Aktan, “They Are Learning Law (2),” Turkish Daily News, 7 Mar 2006, http://www.eraren.org/index.php?Lisan=en\&Page=Makaleler\&MakaleNo=174 (accessed 15 Dec 2011).; Julian Borger, "Darfur Conflict: Sudan's President Charged with Genocide," The Guardian, 15 Jul 2008, 14; Schabas, Genocide in International Law, 12.

50. De Waal, "Review of Gerard Prunier."

51. U.N. Doc. No. E/794, 13-5. See also Soviet Union: Amendment to Article II, U.N. Doc. No. A/C.6/215 (9 Oct 1948); U.N. Doc. No. E/AC.25/SR.22 (27 Apr 1948), 3-7. Cf. UNCG, Article II.

52. U.N. Doc. No. E/794, 13-5. See also Union of Soviet Socialist Republics: Amendments to the Draft Convention (E/794) U.N. Doc. No., A/C.6/215; U.N. Doc. No. E/AC.25/SR.22, 3-7.

53. The report of the drafting committee stated that "it was ... wrong to consider genocide as being an exclusive product of fascism-nazism. In fact, history revealed many previous cases of genocide. As regards the future, it was possible that crimes of genocide would be based on other motives." U.N. Doc. No. E/794, 8.

54. Ibid., 10.

55. U.N. Doc. No. E/794, 13-5. See also U.N. Doc. No. E/CN.4/SR.76 (16 Jun 1948), 13-4.

56. Schabas, "The International Legal Prohibition of Genocide," 169, 176. See also Schabas, "The Law and Genocide," 135; William Schabas, "Convention on the Prevention and Punishment of Genocide," in Encyclopedia of Genocide and Crimes Against Humanity, ed. Dinah Shelton (New York: Macmillan, 2005), 204.

57. William Schabas, "Darfur and the 'Odious Scourge': The Commission of Inquiry's Findings on Genocide," in War Crimes and Human Rights: Essays on the Death Penalty, Justice and Accountability (London: Cameron May, 2008), 756. See also Mahmood Mamdani, Saviors and Survivors: Darfur, Politics, and the War on Terror (New York: Random House, 2009), 70-2, 271-3; Mahmood Mamdani, "The Politics of Naming: Genocide, Civil War, Insurgency," London Review of Books, 8 Mar 2007, http:// www.lrb.co.uk/v29/n05/mahmood-mamdani/the-politics-of-naming-genocide-civil-war-insurgency (accessed 15 Dec 2011); Alexander De Waal, "A Critique of the Public Application by the Chief Prosecutor of the ICC for an Arrest Warrant against Sudanese President Omar al Bashir," Making Sense of Sudan, Jan 2009, 4-12, http://africanarguments.org/2009/02/10/the-icc-vs-bashir-debating-genocidalintent/ (accessed 15 Dec 2011); Alexander De Waal, "The ICC vs. Bashir: Debating Genocidal Intent," Making Sense of Sudan, 9 Feb 2010, http://africanarguments.org/2009/02/10/the-icc-vs-bashir-debating-genocidal-intent/ (accessed 15 Feb 2012); Alexander De Waal, "Moreno Ocampo's Coup de Theatre," Making Sense of Sudan, 29 Jul 2008, http://africanarguments.org/2008/07/29/moreno-ocamposcoup-de-theatre (accessed 15 Dec 2011). Alexander De Waal and Bridget Conley-Zilkic go so far as to suggest that even if entire groups were physically destroyed as a result of famine conditions in Darfur, this would not be "formal" genocide under "the Holocaust paradigm" of the UNCG. Alexander De Waal and Bridget Conley-Zilkic, "Reflections on How Genocidal Killings Are Brought to an End" (paper presented at a seminar on How Genocides End, US Holocaust Memorial Museum, 22 Dec 2006), http://howgenocidesend.ssrc.org/de_Waal/ (accessed 15 Dec 2011). Alex De Waal, "Appealing 
the Genocide Deicion?" Making Sense of Sudan, 15 Mar 2009, http://africanarguments.org/2009/03/15/ appealing-the-genocide-decision/ (accessed $15 \mathrm{Feb} 2012$ ).

58. Schabas, "Problems of International Codification," 287-92. See also Dutton, The Psychology of Genocide, 17,31 .

59. Schabas, "Problems of International Codification," 287-92. Reviewing the Genocide in Cambodia, Documents from the Trial of Pol Pot and Ieng Sary, Schabas found that "the evidence of genocide, at least as presented in this volume, is unconvincing." William Schabas, "Cambodia: Was It Really Genocide?", review of Genocide in Cambodia: Documents from the Trial of Pol Pot and Ieng Sary, ed. Howard De Nike, John Quigley, and Kenneth Robinson, Human Rights Quarterly 23,2 (2001): 470-7. He contended that killing $90 \%$ of the Buddhist monks and the Muslim Cham did not constitute genocide.

60. Schabas, "Problems of International Codification," 293-95; Edward Herman and David Peterson, The Politics of Genocide (New York: Monthly Review Press, 2010), 49-51.

61. Schabas, "Was Genocide Committed in Bosnia and Herzegovina?" 45-7. Schabas wrote that "The Darfur Commission's finding that the summary execution of military-aged men accompanied by evacuation of men and women to camps does not establish genocidal intent is rather more convincing than the reasoning of the International Criminal Tribunal for the former Yugoslavia Trial Chamber, which seemed to suggest that without adult males, a society is doomed." Schabas, "Genocide, Crimes Against Humanity, and Darfur," 1703, 1715-6. He regarded it as "patronizing" to believe that the women and children of Srebrenica could have had their lives shattered by the massacre of the men and boys of their families. He also seemed to accept the argument of the defendants in the Srebrenica cases that the men and boys of Srebrenica were all "combatants." Schabas, "Darfur and the 'Odious Scourge," in War Crimes and Human Rights, 738, 752.

62. Stylianos Malliaris, "Assessing the ICTY Jurisprudence in Defining the Elements of the Crime of Genocide: The Need for a 'Plan," USAK Yearbook of International Politics and Law 3 (2010): 145-71, 163-5.

63. UNCG, Article II.

64. Prosecutor v.Blagojević et al., IT-02-60-T, Trial Chamber, Judgment, 17 Jan 2005, 99 665-6. Of course, all acts are physical in a certain sense, involving the use of matter, even those defined as cultural genocide in the omitted Article III of the UNCG. Physical, here, basically refers to killing.

65. U.N. Doc. No. E/CN.4/SR.73 (24 Jun 1948), 13-4; U.N. Doc. A/C.6/SR.73 (13 Oct 1948), 94.

66. U.N. Doc. No. A/C.6/SR.73, 95.

67. Ibid., 94 .

68. Ibid.

69. Ibid., 97.

70. Soviet Union: Amendments to Article II of Draft Convention on Genocide, A/C.6/223 and Corr. 1 (7 Oct 1948).

71. The delegate from Venezuela explained that Article II as written does not require "physical destruction" but extends to the forced transfer of children to another group where they will lose their original language, customs, and religion. U.N. Doc. No. A/C.6/SR.83 (25 Oct 1948), 195.

72. Ibid.

73. The delegate from Pakistan made this point. Ibid., 194. A British proposal, which was rejected, would have required "grievous bodily" and not simply "serious ... mental harm." United Kingdom: Amendments to Articles II and III, U.N. Doc. No. A/C.6/222 (7 Oct 1948), 1.

74. Prosecutor v. Akayesu, g9 502-4. See also Prosecutor v. Blagojevic and Jokic, Case No. IT-02-60-T, Trial Chamber, Judgement, 17 Jan 2005, gg 607-9; Steven Gorove, "The Problem of 'Mental Harm' in the Genocide Convention," Washington University Law Quarterly (1951), 174-80.

75. U.N. Doc. No. A/C.6/SR.75 (15 Oct 1948), 115-6.

76. Paola Gaeta, The UN Genocide Convention: A Commentary (Oxford: Oxford UP, 2009), 89-102; Sautman, "Cultural Genocide in International Context," 6; Schabas, "Problems of International Codification," 291-2; Schabas, "Genocide Law in a Time of Transition," 171-5; Schabas, "The Law and Genocide," 134-5; Schabas, review of Genocide Convention, 319.

77. U.N. Doc. No. E/794, 18; U.N. Doc. No. E/623 (20 Jul 1948), 538.

78. U.N. Doc. No. E/794, 17. The delegate from Denmark noted, "He was astonished that the Ad Hoc Committee should have submitted so vague a text as a basis for discussion. ... [M]any acts which were not criminal could be designated in those terms." The delegate from the Netherlands called the draft "too vague," which might lead to "abuses." See U.N. Doc. No. A/C.6/SR.83 (25 Oct 1948), 198. The representative of the United States said the draft actually dealt with freedom of expression. U.N. Doc. No. A/C.6/SR.83, 198. 
79. The US delegate argued at one early stage that only racial, national, and religious groups, and not linguistic or ethnic groups, should be protected from genocide. Communication received from the United States of America, U.N. Doc. No. A/401/Add.2 (18 Oct 1947), 4; see also Comments by Governments on the Draft Convention, prepared by the Secretariat and Communications from Non-governmental Organizations, U.N. Doc. No. E/623 (20 Jul 1948), 537. Canada was concerned that cultural genocide would limit the power of provincial legislatures, perhaps having Quebec in mind with regard to its power to encourage the use of the French language, then (as now) very much in the news. Schabas, Genocide in International Law, 184. Canada specifically mentioned its Anglo-Saxon and French populations during the drafting committee's deliberations. U.N. Doc. No. A/C.6/SR.83, 200.

80. Syria: Amendment to Article II, U.N. Doc. No. A/C.6/234 (15 Oct 1948).

81. Ad Hoc Committee on Genocide, Summary Records of Meetings, 21 Sept-10 Dec 1948, U.N. Doc. No. A/C.6/SR.82 (23 Oct 1948), 184.

82. Ibid., 185.

83. Sweden: Amendments to Article II of the Draft Convention, U.N. Doc. No. A/C.6/230 (13 Oct 1948).

84. Ad Hoc Committee on Genocide, Summary Records of Meetings, 21 Sept-10 Dec 1948, U.N. Doc. No. A/C.6/SR.73 (13 Oct 1948), 97.

85. Ibid.

86. Ad Hoc Committee on Genocide, Summary Records of Meetings, 21 Sept-10 Dec 1948, U.N. Doc. No. A/C.6/SR.74 (14 Oct 1948), 98.

87. Ibid., 99.

88. Ad Hoc Committee on Genocide, Summary Records of Meetings, 21 Sept-10 Dec 1948, U.N. Doc. No. A/C.6/SR.75 (15 Oct 1948), 115.

89. Ad Hoc Committee on Genocide, Summary Records of Meetings, 21 Sept-10 Dec 1948, U.N. Doc. No. A/C.6/SR.74 (14 Oct 1948), 104.

90. Ad Hoc Committee on Genocide, Summary Records of Meetings, 21 Sept-10 Dec 1948, U.N. Doc. No. A/C.6/SR.88 (23 Oct 1948), 186, 188, 190.

91. Ad Hoc Committee on Genocide, Summary Records of Meetings, 21 Sept-10 Dec 1948, U.N. Doc. No. A/AC.10/42 (6 Jun 1947), Article II (1)(c).

92. Communication received from the United States of America, U.N. Doc. No. A/401/Add.2, (18 Oct 1947), 4-5.

93. Cf. U.N. Doc. No. E/794, 15 and U.N. Doc. No. A/C.6/223 \& Corr. 1, with UNCG, Article II (b).

94. Commission on Human Rights, Third Session, Summary Record of the Seventy-Sixth Meeting, U.N. Doc. No. E/CN.4/SR.76 (16 Jun 1948), 8.

95. This was true in 2009. Allan Cooper, The Geography of Genocide (Lanham, MD: UP of America, 2009), 16.

96. UNCG, Article II.

97. Draft Convention on the Crime of Genocide, U.N. Doc. No. E/447 (26 Jun 1947), 25.

98. Draft Convention on the Crime of Genocide, prepared by the Secretary-General, U.N. Doc. No. E/447, 26.

99. Schabas, Genocide in International Law, 168.

100. Schabas, "Retroactive Application of the Genocide Convention," University of St. Thomas Journal of Law and Public Policy 4,2 (2010): 36-60, 59.

101. Prosecutor v. Krstić, 57 (partially dissenting statement of Judge Shahabudeen, citing Case of Nikolai Jorkić, Higher Regional Court of Düsseldorf, Judgment, 30 Apr 1999 [Oberlandesgericht Düsseldorf, Urteil vom] BGH 3 StR 215/98, BGH St 45,65ff). The Appeals Chamber in the Krstić case ruled that genocide of "the Bosnian Muslim community in Srebrenica" occurred because the killing of one-fifth of the region's males "had severe procreative implications for the ... community, potentially consigning [it] to extinction" and because "forcible transfer" could also destroy the group. Prosecutor v. Krstić, gg $28,31$.

102. Kadic v. Karadzic, United States Court of Appeals for the Second Circuit, Federal Reporter, Third, vol. 70 (1995), 232-51, certiorari denied, 518 US 1005 (1996).

103. Prosecutor v. Jokic, III (4)(a)(aa); Kadic v. Karadzic, 241-2; S.T.C. No. 237/2005 (26 Sept 2005); S.T. C. No. 227/2007 (22 Oct 2007); John Quigley, The Genocide Convention: An International Law Analysis (London: Ashgate, 2006), 27-33, 38-49; William Schabas, "National Courts Finally Begin to Prosecute Genocide, the "Crime of Crimes," in War Crimes and Human Rights, p. 710-12; Schabas, Genocide in International Law, 390-1; William Schabas, Genocide in International Law: The Crime of Crimes, 2nd ed. (Cambridge: Cambridge UP, 2009), 422-4, 437-8.

104. Superior Tribunal of Justice, Recurso Especial No. 222,653 (Roraima), 1999/0061733-9, Brazil (22 May 2001); Quigley, The Genocide Convention, 48-9. 
105. Bruce Oudes, "De Gaulle Steps into the Nigerian War," The Sun, 17 Nov 1968, K3; Government of India, Ministry of External Affairs, Bangla Desh Documents (1971); 26 U.N. G.A.O.R., 2003rd Plenary Meeting (7 Dec 1971), 14 156; 26 US. S.C.O.R., 1608th Meeting (6 Dec 1971), 27 g 262; United Press International [UPI], "Soviets Seek Air Link with Cyprus," Eugene Register-Guard, 24 Feb 1964, 2A; UPI, "Cyprus Cease Fire Announced," Bangor Daily News, 22 Jul 1974, 1; William Beecher, "10,000 Die from Soviet Chemicals, US Asserts," Boston Globe, 23 Mar 1982, 1; Associated Press, "Policy of Famine Pursued in Afghanistan," Ottawa Citizen, 26 Feb 1985, A12; George H.W. Bush, Address before the 45th Session of the United Nations General Assembly, New York (1 Oct 1990); "The US and Asia: Building Democracy and Freedom," US Department of State Dispatch, 2,46, 18 Nov 1991, http:// findarticles.com/p/articles/mi_m1584/is_n46_v2/ai_11715081/ (accessed 15 Dec 2011); Republic of Turkey, Draft Resolution of the U.N. Commission on Human Rights, E/CN.4/1992/S-2/L.2 (30 Nov 1992); Douglas Bennett, "Statements at Confirmation Hearings," US Department of State Dispatch 4,20, 17 May 1993, http://findarticles.com/p/articles/mi_m1584/is_n20_v4/ai_14028484/pg_3/?tag=content; coll (accessed 15 Dec 2011); Cambodian Genocide Justice Act, United States Code, 12 (2000), title 22, $\$ 2656$ note, 827; Madeleine Albright, "Realism and Idealism in American Foreign Policy Today," US Department of State Dispatch 5,26, 27 Jun 1994, http://findarticles.com/p/articles/mi_m1584/ is_n26_v5/ai_15612798/ (accessed 15 Dec 2011); Strobe Talbott, "U.S. Leadership and the Balkan Challenge," US Department of State Dispatch 6,47 (20 Nov 1995): 859-61, 859; Madeline Albright, "Testimony before the House Appropriations Subcommittee on Foreign Operations, Washington, DC, 15 Apr 1999," US Department of State Dispatch, Apr. 1999, http://findarticles.com/p/articles/mi_m1584/ is_3_10/ai_54772685/ (accessed 15 Dec 2011); Tony Blair, "My Pledge to the Refugees," BBC News, 14 May 1999, http://news.bbc.co.uk/2/hi/uk_news/politics/343739.stm (accessed 21 Feb 2012); Interview of the President by Russian Television, 20 Jun 1999, http://clinton2.nara.gov/WH/New/Europe-9906/ html/Speeches/990620b.html (accessed 15 Dec 2011); "Parliament Bureau, Ecevit Defends Bank Operation,” Turkish Daily News/Financial Times Information, 29 Dec 1999; Al Anfal, Special Verdict Pertaining to Case No 1/C Second/2006, Iraqi High Tribunal, Second Criminal Court/Court of Felonies (24 Jun 2007), 22-4; Al Anfal, Special Verdict Pertaining to Case No 1/C Second/2006, Iraqi High Tribunal, Appellate Chamber (4 Sept 2007), 11-4, 26.

106. Prosecutor v. Akayesu, gg 569-79, 609; Prosecutor v. Krstić, g 11; Prosecutor v. Blagojević, g 624; Prosecutor v. Dragoljub Kunarac, Radomir Kovač, and Zoran Vuković, IT-96-23-A and IT-96-23/1-A, Appeals Chamber, Judgment, 12 Jun 2002), g 98, n. 114; Prosecutor v. Erdemovic, IT-96-22-A, Appeals Chamber, Judgment, 7 Oct 1997 (separate opinion of Judges McDonald and Vohrah), 99 40-87.

107. U.N. Doc. No. A/RES/47/121; U.N. Doc. No. A/RES/48/153; U.N. Doc. No. A/RES/49/205; U.N. Doc. No. A/RES/50/192; U.N. Doc. No. A/RES/51/115; "Bosnia and Herzegovina," in Shelton, Encyclopedia of Genocide and Crimes Against Humanity, 1076.

108. Schabas, Genocide in International Law, 193; see also U.N. Doc. No. A/PV.178, 810-31.

109. U.N. Doc. No. A/C.6/SR.83, 193.

110. Ibid., 196-7, 199, 201-4.

111. Quigley, The Genocide Convention, 104; Martin Shaw, What Is Genocide? (Cambridge: Polity, 2007), 52-8; Gregory Stanton, "Proving Genocide in Darfur: The Atrocities Documentation Project and Resistance to Its Findings," in Genocide in Darfur: Investigating the Atrocities in the Sudan, ed. Samuel Totten and Eric Markusen (London: Routledge, 2006), 186-8; U.N. International Law Commission, Yearbook of the International Law Commission, vol. 2, part 2 (United Nations, 1957), 67.

112. Turkish Penal Code, vol. 2, article 76, law no. 5237 (entered into force 1 Jun 2005), http://www. tuerkeiforum.net/enw/index.php/Translation_of_selected_Articles_of_the_Turkish_Penal_Code (accessed 25 May 2011). Turkey has accused Greek Cypriots, Yugoslavian Serbs, and Han Chinese of genocide by selective massacres. Associated Press, "Cypriots, Turkey Trade Threats," Spokane Daily Chronicle, 13 Mar 1964, 1; Republic of Turkey, Draft Resolution of the U.N. Commission on Human Rights, E/CN.4/1992/S-2/L.2 (30 Nov 1992); "Turkish Premier Says Shelter to Kurdish Leader Will Be Viewed as 'Hostile Act," TRT TV/BBC Monitoring, 22 Jan 1999; "Ecevit Defends Bank Operation," Turkish Daily News/ Financial Times Global News Wire, 29 Dec 1999 ; "China Demands Turkish Retraction," BBC News, 14 Jul 2009, http://news.bbc.co.uk/2/hi/8149379.stm (accessed 15 Dec 2011).

113. William Schabas, "International Justice for International Crimes: An Idea Whose Time Has Come," European Review 14,4 (2006): 421-39, 433-4; Schabas, "Problems of International Codification," 295.

114. Bosnia and Herzegovina v. Serbia and Montenegro: Case Concerning the Application of the Convention on the Prevention and Punishment of the Crime of Genocide, Judgement (26 Feb 2007), International Court of Justice, http://www.icj-cij.org/docket/files/91/13685.pdf (accessed 13 Feb 2012).

115. Ibid., g9 142-8 (separate opinion of Judge ad hoc Kreća). In the ICJ's judgment, there is no "specific characterization of [the Bosnian Muslim] leadership who were massacred. It is not clear what leadership 
is in question-political, military, or intellectual." As David Scheffer points out, "The key paragraphs (370-76) of the majority's decision hardly demonstrate the kind of rigorous investigative and analytical exercise required to establish whether a government's specific intent to commit genocide can be inferred." See Scheffer, "The World Court's Fractured Ruling on Genocide," Genocide Studies and Prevention 2,2 (2007): 123-36, http://dx.doi.org/10.3138/gsp.2.2.123, 126.

116. The Pre-Trial Chamber found that "a proposal made during the drafting of the 1948 UNCG to include in the definition 'measures intended to oblige members of a group to abandon their homes in order to escape the threat of subsequent ill-treatment' was not accepted." Prosecutor v. Omar Hassan Ahmad Al Bashir, ICC-02/05-01/09, 1/95, ICC Pre-Trial Chamber I, Decision on the Prosecution's Application for a Warrant of Arrest (4 Mar 2009), g 143-4 (citing Bosnia v. Serbia [2007], 190, and U.N. Doc. No. A/C6/234 [15 Oct 1948]). The Appeals Chamber rejected the view, sometimes echoed in Schabas's work, that any reasonable doubt concerning a perpetrator's intent should be removed by the prosecutor before using the word "genocide" to commence an investigation or trial for the crime. Prosecutor v. Al Bashir, ICC-02/05-10/09-0A, Appeals Chamber (3 Feb 2010), http://www.docstoc.com/docs/ 24383863/Prosecutor-v-al-Bashir, (15 Nov 2011).

117. Prosecutor v. Al Bashir, 6.

118. Cf. International Commission of Inquiry on Darfur (ICID), Report to the United Nations SecretaryGeneral_ Pursuant to Security Council Resolution 1564 of 18 September 2004 (25 Jan 2005), g 513, and Prosecutor v. Al Bashir, 99292 .

119. Prosecutor v. Blagojević, 646; Prosecutor v. Krstić, 513. The Trial Chamber I of the ICTY has ruled that "The forcible transfer out of the [Srebrenica] enclave of the women, children and elderly, in combination with those killings, or on its own, caused the survivors to suffer serious mental harm." Prosecutor v. Blagojević, 971 . It has also stated that "the forced migration of civilians" constituted a form of genocide as "part of a deliberate campaign by the Serbs to eliminate Muslim control of, and presence in, substantial parts of Bosnia-Herzegovina." Prosecutor v. Blagojević, g 663 (emphasis original). See also Prosecutor v. Blagojević, g9 649-54. The Trial Chamber in Krstić ruled that "inhuman treatment ... and deportation are among the acts which may cause serious bodily or mental injury." Prosecutor v. Krstić, 513. William Schabas, The UN International Criminal Tribunals: The Former Yugoslavia, Rwanda, and Sierra Leone (Cambridge: Cambridge UP, 2006), 176.

120. Prosecutor v. Radovan Karadzić and Ratko Mladić, IT-95-5-R61 and IT-95-18-R61 (review of the Indictments pursuant to Rule 61, 11 Jul 1996), 93.

121. Prosecutor v. Blagojević, 666.

122. Prosecutor v. Akayesu, 99 506, 523. See also Prosecutor v. Musema, ICTR-96-13-A, Trial Chamber, Judgment, 19 Jan 2000, 157; Prosecutor v. Rutanga, ICTR-96-3-T, Trial Chamber, Judgment, 6 Dec 1999, 54.

123. For example, in Prosecutor v. Jelisić, there was no evidence as to the accused's place in the chain of command, the accused acted arbitrarily and randomly as opposed to singling out Muslim leaders, and only 66 bodies were exhumed out of a camp population of 600 to 700 detainees, even though the prosecutor alleged hundreds of deaths. Prosecutor v. Jelisić, IT-95-10-A, Appeals Chamber, Judgment (5 Jul 2001), 99 64, 90, 93. In any event, the Appeals Chamber concluded that the Trial Chamber could properly have inferred genocidal intent under the circumstances. Prosecutor v. Jelisić, 75 . In Prosecutor v. Sikirica et al., ICTY-95-8-T, Trial Chamber, Judgment, 3 Sept 2001, 73, the accused targeted only a "very small" percentage of the relevant municipality, fewer than three percent. In Prosecutor v. Stakić, IT-97-24-T, Trial Chamber, Judgment, 31 Jul 2003, gg 553-4, fewer than 13\% of the people passing through the relevant area were killed, and this figure related to the same municipality in Sikirica in which fewer than $3 \%$ of residents were affected by genocidal acts (not just killing), and, moreover, the accused announced that any Muslims who had not killed Serbs could return to their homes after the war. In Prosecutor v. Brdānin, ICTY-99-36-T, Trial Chamber, Judgment, 1 Sept 2004), 9967,974 n. 2448, 978, about $95 \%$ of the populations of the relevant municipalities survived, and the vast majority of the victim population (nearly 300,000 Bosnian Muslims and Croats) was not deported. These are the cases cited in Schabas, "Genocide and the International Court of Justice," 112.

124. Prosecutor v. Bagosora et al., ICTR-98-41-T, Trial Chamber I, Judgment, 18 Dec 2008, gg 2095-110, 2158.

125. Prosecutor v. Jean Kambanda, ICTR 97-23-S, Trial Chamber, Judgment (4 Sept 1998), aff'd, ICTR 9723-A, Appeals Chamber, Judgment (19 Oct 2000), 118; see also Prosecutor v. Kayishema and Ruzindana, ICTR-95-1-T, Trial Chamber, Judgment, 21 May 1999, gg 93, 527; Prosecutor v. Gacumbitsi, ICTR-01-64-I, Trial Chamber, Judgment, 20 Jun 2001, gg 35, 99; Prosecutor v. Nahima et al., ICTR99-52-T, Trial Chamber, Judgment, 3 Dec 2003), 115; Prosecutor v. Semanza, ICTR-97-20-T, Trial 
Chamber III, Judgment and Sentence, 15 May 2003, gg 476-7; Prosecutor v. Muhimana, ICTR-951B-T, Trial Chamber I, Judgment and Sentence, 25 Apr 2005, 166.

126. Schabas, "Darfur and the 'Odious Scourge," Leiden Journal of International Law; Schabas, "Genocide, Crimes Against Humanity, and Darfur,” 1703-21; William Schabas, "International Justice for International Crimes," 421, 433-4; William Schabas, "Prosecuting Dr. Strangelove, Goldfinger, and the Joker at the International Criminal Court: Closing the Loopholes," Leiden Journal of International Law 23,4 (2010): 847-53.

127. Malliaris, "Assessing the ICTY Jurisprudence," 154-5, 158-9, 164-5; Schabas, "Genocide, Crimes Against Humanity, and Darfur," 1711.

128. William Schabas, "Genocide and the International Court of Justice," 111, 114; William Schabas, "Whither Genocide? The International Court of Justice Finally Pronounces," Journal of Genocide Research 9,2 (2007): 183-92, 190.

129. Schabas, "Darfur and the 'Odious Scourge," in War Crimes and Human Rights, p. 816; Schabas, "State Policy as an Element of International Crimes," 970-2.

130. UNCG, Article IV.

131. U.N. Doc. No. A/C.6/SR.73, 91-3.

132. Ibid., 89-90.

133. U.N. Doc. No. E/447, 20.

134. Ibid., 23.

135. U.N. Doc. No. E/794, 13-5. See also Soviet Union: Amendment to Article II; UN Doc. E/AC.25/SR.22, 3-7. Cf. UNCG, Article II.

136. Second Decennial Edition of the American Digest, vol. 12 (St. Paul: West Publishing, 1920), 124.

137. Caroline Fournet, The Crime of Destruction and the Law of Genocide: Their Impact on Collective Memory (London: Ashgate, 2007), 63-4.

138. Ibid. See also Prosecutor v. Jelisic, 47.

139. U.N Doc. No. A/C.6/SR.61-140 (21 Oct 1948), 168.

140. Ibid., 158.

141. Ibid.

142. Ibid., 160.

143. Ibid., 153-4.

144. Ibid., 155.

145. U.N Doc. No. A/C.6/SR.61-140 (21 Oct 1948), 166-7.

146. Ibid., 167.

147. Ibid., 170.

148. E.g., Antonin Scalia, A Matter of Interpretation: Federal Courts and the Law (Princeton: Princeton UP, 1998), 36.

149. William Schabas, "Developments in the Law of Genocide," Yearbook of International Humanitarian Law 5 (2002): 131-65, 156.

150. Schabas, "Genocide and the International Court of Justice," 112; Schabas, "Darfur and the "Odious Scourge," Leiden Journal of International Law, 875-6.

151. Schabas, "State Policy as an Element of International Crimes," 972.

152. Schabas, Genocide in International Law, 9. The available evidence suggests that survivors of the Rwandan Genocide are anxious to prevent other genocides and do not claim a privileged position in the history of the world by minimizing other crimes. Laureen Ellison, "Personal Tragedy Leads to Formation of Charity Group," The Lantern, 7 Apr 2005, http://www.thelantern.com/2.1345/personal-tragedyleads-to-formation-of-charity-group-1.85357 (accessed 15 Dec 2011). Lemkin was not hesitant to recognize other genocides, despite having nearly died in the Holocaust and having lost many numbers of his family. See Jones, Genocide, 55.

153. Aktan, "The Armenian Problem and International Law"; Katz, "The 'Unique' Intentionality of the Holocaust," 174-5; Lewy, The Armenian Massacres, 204, 245-9, 260-5; William Schabas, "Retroactive Application," 59; Stanford Shaw and Ezel Kural Shaw, History of the Ottoman Empire and Modern Turkey, vol. 2 (Cambridge: Cambridge UP, 1977), 316-7.

154. Schabas, "Retroactive Application," 59.

155. Ibid., 57-8.

156. Ibid., 56.

157. Schabas wrote in 2010, "The payment of reparations by Germany in the aftermath of the war was made out of a sense of responsibility but was in no sense a result of a legal claim against an unwilling defendant." Ibid., 57.

158. Ibid. 
159. United States District Court for the Eastern District of New York, In re Agent Orange Product Liability Litigation, Federal Supplement, second, vol. 373 (2005), 59-64.

160. Ibid., 63 .

161. M. Cherif, Bassiouni, International Criminal Law: Sources, Subjects, and Contents (Leiden: Brill, 2008), 173; Theo Van Boven, "Victim's Right to a Remedy and Reparation: The New United Nations Principles and Guidelines," in Reparations for Victims of Genocide, War Crimes and Crimes against Humanity, ed. Carla Ferstman et al. (Leiden: Martinus Nijhoff, 2009), 33; Jordan Paust, "Opinion," In re Agent Orange Product Liability Litigation, Doc. No. 2005 WL 6041235 (5 Jan 2005), http://www.westlaw.com (accessed 15 Dec 2011).

162. United States District Court for the District of New Jersey, In re Nazi Era Cases Against German Defendants Litigation, Federal Supplement, Second, vol. 129 (2001), 372.

163. Ibid.

164. Nehemiah Robinson, "Material Jewish Claims Against Germany," The Canadian Jewish Chronicle (21 Dec 1951), 16, 26.

165. Ibid., 25 .

166. Movsesian v. Victoria Versicherung, United States Court of Appeals for the Ninth Circuit, Federal Reporter, Third, vol. 629 (2010), 903-4; Deirmenjian v. Deutsche Bank, United States District Court for the Central District of California, Federal Supplement, Second, vol. 526 (2007), 1073-6.

167. Roger Smith, Erik Markusen, and Robert Jay Lifton,"Professional Ethics and the Denial of the Armenian Genocide," Holocaust and Genocide Studies 91 (1995): 1-22.

168. Ibid., 13 .

169. Ibid., 14 .

170. La Cantuta v. Peru, Inter-Am. C.H.R., OEA/ser. C./ No.162 (29 Nov 2006), 222.

171. Philippe Sands, Torture Team: Rumsfeld's Memo and the Betrayal of American Values (New York: Macmillan, 2009), 23, 31, 49, 71-8, 85, 173-90; Garry Wills, Bomb Power: The Modern Presidency and the National Security State (New York: Penguin, 2011).

172. Israel Charny defines "definitionalism" as "a damaging style of intellectual inquiry based on a perverse, fetishistic involvement with definitions to the point where the reality of the subject under discussion is lost." See Charny, How Can We Commit the Unthinkable? Genocide: The Human Cancer (Boulder, CO: Westview, 1982), 59. Stanton objects to definitionalism as incorrectly ignoring the "in whole or in part" clause of the UNCG by assuming that (1) genocide must be "total or whole," (2) "ethnic cleansing" does not amount to genocide because the group members who are driven out of their homeland may survive, and/or (3) genocidal intent requires an apolitical, ahistorical racist motive. See Gregory Stanton, "The 12 Ways to Deny a Genocide: Genocide Emergency: Darfur, Sudan" (15 Jun 2005), http:// www.genocidewatch.org/aboutgenocide/12waystodenygenocide.html (accessed 15 Dec 2011).

173. Aktan, "They Are Learning Law (2)".

174. Ibid.

175. William Schabas, "Definitional Traps' and Misleading Titles," Genocide Studies and Prevention 4,2 (2009): 177-83, http://dx.doi.org/10.3138/gsp.4.2.177, 177, 181.

176. Samuel S. Kim, "China and the United Nations," in China Joins the World: Progress and Prospects, ed. Elizabeth Economy and Michel Oksenberg (New York: Council on Foreign Relations, 1999), 64-5.

177. "Meanwhile, in Darfur," The New York Sun, 4 Feb 2005.

178. "Pro-Sudan Groups Ask ICC Judges to Reject Genocide Appeal," Sudan Tribune, 27 Jul 2009.

179. Prosecutor v. Popović et al., IT-05-88-I, Trial Chamber II, Decision on the Admissibility of the Expert Report and Proposed Expert Testimony of Professor Schabas, 1 Jul 2008, 8.

180. Prosecutor v. Karadžić, IT-95-5/18-I, Trial Chamber III, Defendant's Pre-trial Brief, 29 Jun 2009, http://www.icty.org/case/karadzic/4 (accessed 15 Dec 2011), gg 84-93,.

181. Schabas, "Retroactive Application," 47-9, 58-9.

182. Ibid., 36, 56-7. Schabas notes that the head of the US delegation to the London Conference defined genocide as including "destruction of racial minorities and subjugated populations by such means and methods as (1) underfeeding; (2) sterilization and castration; (3) depriving them of clothing, shelter, fuel, sanitation, medical care; (4) deporting them for forced labor; (5) working them in inhumane conditions." Ibid., 43. In 1918, the press widely reported that 30,000 Armenians were starving in the vicinity of Mosul and Tabriz, in the Ottoman Empire and Persia, respectively. See Associated Press, "Armenians Are Starving in Persia," Meridian Morning Record (Connecticut), 27 Dec 1918, 4; "Millions Armenians Starving in Turkey," Los Angeles Times, 26 Dec 1918, I2. In 1919, the American Food Commissioner for the Near East, Howard Heinz, estimated that 500,000 displaced Armenians were at risk of starvation, the population was eating grass, and typhus was spreading in an epidemic. "Finds Armenians Starving; 500000 Without Food, Says Heinz - Credits Cannibalism Tale," The New York Times, 
23 May 1919. In 1922, the Associated Press reported that the Armenian population was slowly becoming extinct from typhus and starvation. Associated Press, "Armenians Reported to Be in Dire Want," Prescott Evening Courier, 7 Apr 1922, 1. In 1926, The New York Times published a letter to the editor stating that hundreds of thousands of deported Armenians were starving in Syria. "Turkish Treaty Issues," The New York Times, 25 May 1926.

183. Schabas, "Retroactive Application," 59.

184. Schabas, "Cambodia: Was It Really Genocide?," 474.

185. UNCG Article II(c)

186. UNCG Article II(d) and II(e).

187. Peter H. Maguire, Facing Death in Cambodia (New York: Columbia UP, 2005), 51; Barry Kramer, "Tales of Terror: Cambodian Refugees Tell a Story of Hunger, Regression and Death: Complainers and Their Kin Are Said to Be Executed," Wall Street Journal, 22 Nov 1978; Jonathan Sikes, "Deadly Khmer Rouge Hold Key to Peace in Kampuchea," Toronto Star, 6 Mar 1988, H5.

188. Ben Kiernan, Genocide and Resistance in Southeast Asia: Documentation, Denial and Justice in Cambodia and East Timor (New Brunswick, NJ: Transaction), 217-8; Kiernan, Blood and Soil, 547-9.

189. Associated Press, "Khmer Rouge Decimated Phnom Penh," The Madison Courier, 3 Aug 1983, 2.

190. Schabas, "Justice, Democracy, and Impunity," 551.

191. Herman and Peterson, The Politics of Genocide, 46-51, 125-8; Alan Kuperman, The Limits of Humanitarian Intervention: Genocide in Rwanda (Washington, DC: Brookings Institution Press, 2001), 112-3; Schabas, "Genocide and the International Court of Justice"; Schabas, "Problems of International Codification," 293-5. The 200,000 estimate was available in 1998. Ewa Tabeau and Jakub Bijak, "War-related Deaths in the 1992-1995 Armed Conflicts in Bosnia and Herzegovina: A Critique of Previous Estimates and Recent Results," European Journal of Population 21,2-3 (2005): 187-215, 193. The 12,000 to 18,300 estimate was available in 2000. See Paul B. Spiegel and Peter Salama, "War and Mortality in Kosovo, 1998-99: An Epidemiological Testimony," The Lancet 355,9222 (2000): 2204-9. See also Eric Victor Larson and Bogdan Savych, Misfortunes of War: Press and Public Reactions to Civilian Deaths in Wartime (Santa Monica: Rand, 2007), 69. The 305,000 figure was available in 2008. See Jan Zwierzchowski and Ewa Tabeau, "The 1992-95 War in Bosnia and Herzegovina: Census-Based Multiple System Estimation of Casualties' Undercount," The Households in Conflict Network and German Institute for Economic Research (1 Feb 2010), 20.

192. Schabas, "Darfur and the 'Odious Scourge," Leiden Journal of International Law, 881.

193. Prosecutor v. Krstić, 1, n. 3; Helge Brunborg, Torkild Hovde Lyngstad, and Henrik Urdal, “Accounting for Genocide: How Many Were Killed in Srebrenica?," European Journal of Population, 19,3 (2003): 229-48, 245.

194. De Waal and Conley-Zilkic, "Reflections on How Genocidal Killings Are Brought to an End"; Alex De Waal, “Appealing the Genocide Decision?,” Making Sense of Sudan, 15 Mar 2009, http://africanarguments.org/2009/03/15/appealing-the-genocide-decision/ (accessed 15 Feb 2012); Schabas, "Darfur and the 'Odious Scourge," Leiden Journal of International Law; Schabas, "Genocide, Crimes Against Humanity, and Darfur"; Schabas, "Definitional Traps," 179; William Schabas, "An Unappealing Appeal," PhD Studies in Human Rights, 14 Mar 2009, http://humanrightsdoctorate.blogspot.com/2009/ 03/unappealing-appeal.html (accessed 15 Dec 2011). Even more remarkable is one book that cavalierly mocks a non-profit organization's use of the 400,000 figure in efforts to halt the genocide, while failing to mention its scientific basis. Julie Flint and Alexander De Waal, Darfur: A New History of a Long War (London: Zed Books, 2008), 186. The estimate of 70,000 deaths was made available by the World Health Organization in 2004. Hannibal Travis, Genocide in the Middle East: The Ottoman Empire, Iraq, and Sudan (Durham, NC: Carolina Academic Press, 2010), 462. The estimate of 400,000 to 450,000 deaths was widely published in the press in 2006. See Travis, Genocide in the Middle East, 463. It, too, had a scientific basis. John Hagan, Wenona Rymond-Richmond, and Patricia Parket, "The Criminology of Genocide: Death and Rape in Darfur," Criminology 43,3 (2005): 525-61; Coalition for International Justice, "New Analysis Claims Darfur Deaths Near 400,000," Sudan Tribune, 21 Apr 2005, http://www.sudantribune.com/New-Analysis-Claims-Darfur-Deaths,9236 (accessed 15 Dec 2011).

195. Schabas, “Genocide, Crimes Against Humanity, and Darfur,” 1703, 1715-6.

196. ICID report, 9 242, 248, 253, 272, 273, 274, 278, 287, 343, 344, 365, 368.

197. William Schabas, The UN International Criminal Tribunals: The Former Yugoslavia, Rwanda and Sierra Leone (Cambridge: Cambridge UP, 2001), 167.

198. Schabas, Genocide and International Law, 135.

199. UNCG, Article 1. 
200. At these trials, only non-Indonesians, who bore the least responsibility for crimes against humanity in East Timor, were punished. Caitlin Reiger and Marieke Wierda, The Serious Crimes Process in TimorLeste: In Retrospect (International Center for Transitional Justice, 2006), 2-7, 18, 20; Timothy Lindsey, Indonesia, Law and Society (Annandale, Australia: Federation Press, 2008), 443. Iraq is a unique case due to the Iraqi High Tribunal, established with substantial US influence and support, but nevertheless still a domestic institution. Michael Scharf and Michael Newton, "The Iraqi High Tribunal's Dujail Trial Opinion," ASIL Insights 10,34 (2006), http://www.asil.org/insights061218.cfm (accessed 15 Dec 2011).

201. Schabas, "Darfur and the 'Odious Scourge," Leiden Journal of International Law, 877; Schabas, "Genocide, Crimes Against Humanity, and Darfur," 1711.

202. Malliaris, "Assessing the ICTY Jurisprudence," 131; Schabas, “The Jelisic Case," 136.

203. Gérard Prunier, The Rwanda Crisis: History of a Genocide (New York: Columbia UP, 1995), 274.

204. Schabas, Genocide in International Law, 102.

205. Prosecutor v. Bagosora et al., $\mathbf{g g}$ 2095-110.

206. Gérard Prunier, Darfur: A 21st Century Genocide, 3rd ed. (Ithaca, NY: Cornell UP, 2008), 156.

207. Carla Del Ponte, Madame Prosecutor: Confrontations with Humanity's Worst Criminals (New York: Other Press, 2009), 179, 183-4, 226-9; "Profile: Croatian President Franjo Tudjman Dies at Age 77," National Public Radio, 11 Dec 1999, http://www.npr.org (accessed 15 Dec 2011); Raymond Bonner, "Croatia Branded as Another Balkans Pariah," The New York Times, 3 Mar 1999, http://www.nytimes. com/1999/03/03/world/croatia-branded-as-another-balkans-pariah.html?pagewanted=2 (accessed 15 Dec 2011).

208. David Scheffer, "The World Court's Fractured Ruling on Genocide," Genocide Studies and Prevention 2,2 (2007): 123-36, 128. See also Antonio Cassese, "A Judicial Massacre: The International Court Has Set an Unrealistically High Standard of Proof for Finding Serbia Complicit in Genocide," Op-Ed, The Guardian, 27 Feb 2007, http://bit.ly/gQj6WF (accessed 15 Dec 2011).

209. Eric Reeves, "Darfur and International Justice," Dissent 56,3 (2009): 13-8.

210. Schabas, "The Jelisic Case," 133.

211. Schabas, "Genocide and the International Court of Justice," 112.

212. Ad Hoc Committee on Genocide, Summary Records of Meetings, 21 Sept-10 Dec 1948, U.N. Doc. No. A/C.6/SR.61-140 (20 Oct 1948), 156.

213. Ibid., 157. 